\title{
A Closer Look into the Role of Protein Tau in the Identification of Promising Therapeutic Targets for Alzheimer's Disease
}

\author{
Rubayat Islam Khan 1,+ (D), Saif Shahriar Rahman Nirzhor ${ }^{1,+}$ and Barnaly Rashid ${ }^{2, *}$ (D) \\ 1 Department of Pharmacy, BRAC University, Dhaka 1212, Bangladesh; rubayat.khan@bracu.ac.bd (R.I.K.); \\ saif.rahman@bracu.ac.bd (S.S.R.N.) \\ 2 Harvard Medical School, Harvard University, Boston, MA 02114, USA \\ * Correspondence: barnaly_rashid@hms.harvard.edu \\ + These authors contributed equally to this work.
}

Received: 22 July 2018; Accepted: 24 August 2018; Published: 26 August 2018

\begin{abstract}
One of the most commonly known chronic neurodegenerative disorders, Alzheimer's disease (AD), manifests the common type of dementia in $60-80 \%$ of cases. From a clinical standpoint, a patent cognitive decline and a severe change in personality, as caused by a loss of neurons, is usually evident in AD with about 50 million people affected in 2016. The disease progression in patients is distinguished by a gradual plummet in cognitive functions, eliciting symptoms such as memory loss, and eventually requiring full-time medical care. From a histopathological standpoint, the defining characteristics are intracellular aggregations of hyper-phosphorylated tau protein, known as neurofibrillary tangles (NFT), and depositions of amyloid $\beta$-peptides (A $\beta$ ) in the brain. The abnormal phosphorylation of tau protein is attributed to a wide gamut of neurological disorders known as tauopathies. In addition to the hyperphosphorylated tau lesions, neuroinflammatory processes could occur in a sustained manner through astro-glial activation, resulting in the disease progression. Recent findings have suggested a strong interplay between the mechanism of Tau phosphorylation, disruption of microtubules, and synaptic loss and pathology of AD. The mechanisms underlying these interactions along with their respective consequences in Tau pathology are still ill-defined. Thus, in this review: (1) we highlight the interplays existing between Tau pathology and $\mathrm{AD}$; and (2) take a closer look into its role while identifying some promising therapeutic advances including state of the art imaging techniques.
\end{abstract}

Keywords: protein tau; Alzheimer's disease; neurodegenerative disease; synaptic dysfunction; $\mathrm{A} \beta$-peptides; tau-imaging

\section{Introduction}

Originally, tau was recognized as a protein in the cytoplasm and was tagged with the role of stabilizing microtubules. Tau is coded by the microtubule associated protein tau (MAPT) gene and is usually abundant in neuronal cells. It has shown six different isoforms in neuronal cells because of differential splicing and is associated with multi-faceted functions even though some of these functions are not clearly understood [1,2]. This protein has been shown to play a critical role in Alzheimer's disease (AD) pathology and could be the future in terms of treating AD and engendering new therapeutic targets. Several studies have tried and unfortunately failed to successfully target the $\mathrm{A} \beta$-peptide buildup in the brain. Recent studies indicate that it may as well be the case that the $A \beta$ pathology becomes significant many years after tau aggregations start to form in an AD patient $[3,4]$. These findings provide impetus for shifting the focus from the $A \beta$ pathology to the role of protein tau in $\mathrm{AD}$, so that effective strategies for treating $\mathrm{AD}$ may be identified [4-6]. 
Primarily, tau facilitates the assembly of microtubules and the regulation of their stability, thereby eventuating cytoskeleton maintenance, organelle axonal transport and overall neuronal morphology [7-9]. In addition, tau is pivotal in stabilizing genomes and protecting DNA integrity [10-12]. With normal human aging, the brain becomes vulnerable to neuronal tauopathies and increased accumulation of protein tau in glial cells. Primary age related tauopathy (PART) and aging related tau astrogliopathy (ARTAG) are recently introduced neuropathological entities. The morphological spectrum of tau immunoreactivity as present in glial cells of the aging human brain is described by ARTAG, regardless of the existence of any concurrent neurological disorders [13]. Neurofibrillary Tangles (NFT) are hyperphosphorylated tau protein aggregates most commonly known as a primary marker of Alzheimer's disease. NFT are abundantly present in neurons of old-aged individuals as described by PART, with cognitive changes ranging from normal to amnestic [14]. The majority of Tau proteins are located in the axons while the dendrites consist of a smaller proportion physiologically distributed in them. Even though, their post synaptic function still remains imprecise, tau has been previously implicated in synaptic plasticity. [15-19]. In addition to axons and dendrites, nuclear tau are involved in the regulation of transcriptional activity and DNA/RNA maintenance under various physiological conditions $[10,11,20,21]$. Recent evidences signify Tau's role as a signaling molecule in the regulation of the brain insulin pathway where it is implicated in the inhibition of phosphatase and tensin homolog (PTEN) [22,23]. Various etiological factors contribute to the abnormal phosphorylation of tau and subsequent NFT generation and cognitive dysfunction. A schematic of such mechanisms is outlined in Figure 1.

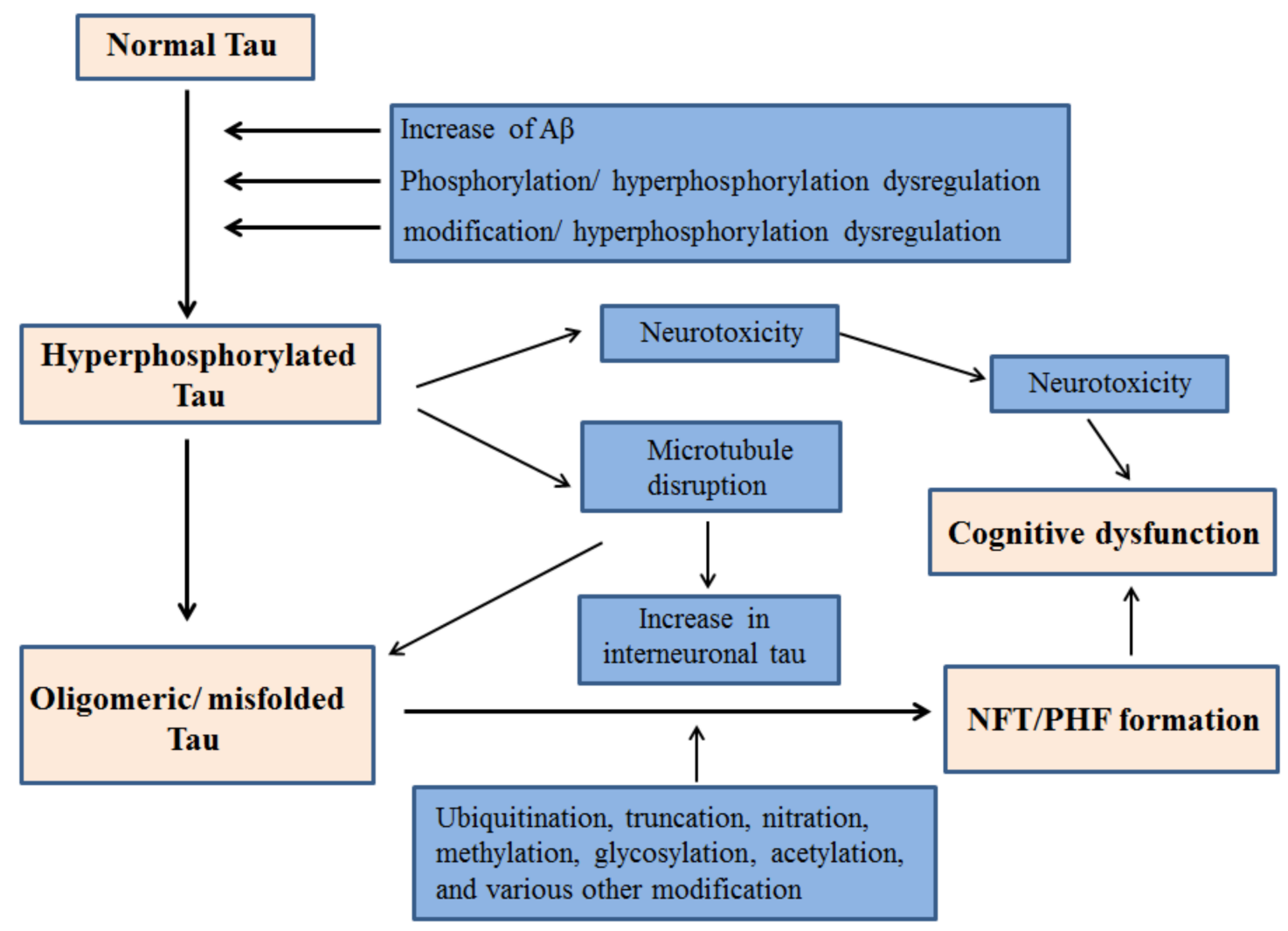

Figure 1. Proposed mechanism of NFT generation leading to cognitive dysfunction by hyperphosphorylated Tau.

\section{Tau Hyperphosphorylation in AD}

The miscellaneous attributes and interactions of Tau with its protein analogues are governed by phosphorylation, ubiquitination, truncation, nitration, methylation, glycosylation, acetylation and 
various other post-translational modifications (PTMs) [24,25]. The microtubule binding region and proline-rich domain of Tau pertain 85 putative phosphorylation sites [26,27]. These phosphorylation sites are identified through the use of mass spectroscopy or phosphor-specific antibodies [28,29]. Phosphorylation states in tauopathies are governed by a number of serine/threonine/tyrosine kinases as well as phosphatases [28]. The intriguing process of tau phosphorylation in AD comprises of tau phosphorylation early in the pathogenesis, formation of the epitopes, initiation of structural changes that promote the activity of secondary kinases; thus following a hierarchical process. A number of studies have demonstrated that the epitopes detected by the antibody AT100 and recognizing paired-helical filaments (PHF) are attributed to the sequential phosphorylation by GSK3 $\beta$ and PKA at Ser214 and Thr212, in addition to Thr 205, Ser202, Ser199 and Thr205 phosphorylation [30,31]. Immune cells can recognize the epitopes generated by Tau phosphorylation. The activation of Tau is enhanced by the expression of Tau by microglial cells [27]. However, the detailed processes resulting in Tau phosphorylation still remain to be explored but accordingly, structural changes promote its detachment from microtubules thereby, producing soluble free tau in high quantities. This gives rise to different degrees of neurotoxicity as Tau hyperphosphorylation favors a gradual self-assembly of Tau, transforming into oligomeric forms and PHF through the disease progression [28].

The enhancement of tau phosphorylation arises from the activity of a number of tyrosine (Tyr) kinases and some serine/threonine (Ser/Thr) kinases. The casein kinases, Ser/Thr kinases GSK-3 $\beta$, and cyclin-dependent kinase 5 (cdk5) phosphorylate tau in AD and are instrumental in the progression of the disease. Researchers have also regarded them as efficient therapeutic targets that hold significant promises against tau-induced toxicity [28,32]. In general, Tau is phosphorylated at a greater number of sites by proline-directed kinases as compared to phosphorylation by kinases that are not directed by proline. However, such kinases (e.g., PKA/calcium/calmodulin kinase II) phosphorylates tau at very few sites but they facilitate the progressive tau phosphorylation by kinases that are proline-directed, namely GSK-3 $\beta$ and cdk5 [33,34]. Abnormal tau phosphorylation is a key player in AD progression and pathogenesis. In different brain regions, the phosphorylation patterns of numerous proteins are altered synergistically; thus transitioning to a symptomatic state of the disease. A large number of abnormally phosphorylated Tau are crucial in synaptic function and cytoskeletal maintenance [35]. In addition to phosphorylation of tau at 42 residues, GSK-3 $\beta$ regulates various other cellular processes and is a key player in the pathogenesis of AD [28]. Table 1 highlights some major enzymes that cause tau phosphorylation at various Ser/Thr sites. In various animal models, GSK- $3 \beta$ has shown to stimulate phosphorylation of tau in neuronal cell cultures, promote the formation of tangle-like filaments, eventuate tau hyperphosphorylation, resulting in cognitive decline [36-38]. Presenilin 1 -a $\gamma$-secretase complex modulates the regulation of tau phosphorylation mediated by GSK-3 $\beta$. Presenilin 1 also depicted enhanced ability to bind and stimulate tau-directed kinase activity by GSK-3 $\beta$ in AD-related mutations [39]. In diverse neurodegenerative conditions including AD, GSK-3 $\beta$ facilitates cell apoptosis. This is facilitated by the proapoptotic stimuli that affect the distribution of GSK-3 $\beta$ within the cells, thereby initiating the cell death signaling networks. Studies conducted in SH-SY5Y cell lines (human neuroblastoma cells)have shown that GSK-3 $\beta$ is localized primarily in the cytosol, however the post-apoptotic intercession facilitates its aggregation in the nucleus where it interacts with nuclear substrates [40]. NFT-tau pathogenesis in AD progresses in a spatio-temporal manner $[3,9,41,42]$. This is strikingly different from the process of the deposition of $A \beta$ plaque where the pattern of localization and quantity is of little significance in the pathogenesis of AD, and leads to gradual cognitive decline $[43,44]$. The loss of neurons is more profound as compared to NFT formation in the AD brain [44]. 
Table 1. Some major enzymes and their sites of Tau phosphorylation.

\begin{tabular}{clc}
\hline Enzyme & \multicolumn{1}{c}{ Phosphorylation sites } & Reference \\
\hline PKA & $\begin{array}{l}\text { Ser-195, Ser-198, Ser199, Ser-202, Ser-214, Ser-235, Ser-258, } \\
\text { Ser-262, Ser-324, Ser-356, Ser-409, Ser-412, Ser-413, Ser422, } \\
\text { Ser-435, Thr-205, Thr-212, Thr-217, Thr-231 }\end{array}$ & {$[45-50]$} \\
\hline PKB/Akt & Ser-214, Thr-212 & {$[51]$} \\
\hline PKC & Ser-258, Ser-293, Ser-324, Ser-352 & {$[52]$} \\
\hline PKN & Ser-214, Ser-258, Ser-320, Ser-352 & {$[52]$} \\
\hline AMPK & Ser-262, Ser-396, Ser-404, Thr-231 & {$[53,54]$} \\
\hline CDK5 & Ser-199, Ser-202, Ser-214, Ser-235, Ser-396, Ser-404, Thr-181, & {$[55,56]$} \\
\hline & Thr-205, Thr-212, Thr-217, Thr-231 & {$[57]$} \\
\hline ERK 1/2 & Ser-46, Ser-199, Ser-202, Ser-235, Ser-396, Ser-404, Ser-422, Thr-50, & \\
\hline & Thr-153, Thr-181, Thr-205, Thr-212, Thr-217 & {$[56,58-60]$} \\
\hline GSK-3 3 & Ser-46, Ser-184, Ser-199, Ser-202, Ser-214, Thr-50, Thr-181, \\
& Thr-205, Thr-212, Thr-217, Thr-231 &
\end{tabular}

Abbreviations: PKA, Protein kinase A; PKB, Protein kinase B; PKC, Protein kinase C; PKN, Protein kinase N; AMPK, Adenosine monophosphate-activated kinase; CDK5, Cyclin-dependent kinase; ERK, Extracellular signal-regulated kinase; GSK-3 $\beta$, Glycogen synthase kinase- $3 \beta$.

\subsection{GSK-3ß Inhibition in Tau}

Tau hyperphosphorylation and NFT formation is a direct outcome of GSK- $3 \beta$ mediated cognitive decline. The first sign of the disease is identified by the moderate somatodendritic accumulation of nonfibrillar tau that is conformationally altered [61]. Though it is well established that tau's function in the stabilization of microtubules is attenuated by its hyperphosphorylation, however its constructive part in tau aggregation still remains ill-defined. Studies have previously emphasized that hyperphosphorylation has a positive correlation with PHF formation, however recent investigations have suggested that just hyperphosphorylation is not sufficient enough for the formation of fibrils, although increased phosphorylation promotes oligomer formation [62,63]. Apolipoprotein E (ApoE) is a class of proteins with implications in lipid metabolism in the body with attributed importance in $\mathrm{AD}$. In addition to influencing the accumulation and removal of $A \beta$, isoforms of ApoE can condition tau and microtubule through modulation of signal transduction pathways that are responsible for tau kinase activity [64]. In a study conducted by Hoe et al., the treatment of primary neurons with three different ApoE isoforms showed decreased aggregation of phosphorylated tau, increased levels of unphosphorylated tau, inhibited phosphorylation of GSK-3 $\beta$ and altered the localization pattern of tau in neuronal cells through extracellular interactions [64]. ApoE isoforms might also bind tau specifically and inhibit tau phosphorylation. GSK-3 mediated tau phosphorylation is increased by isoform ApoE4 due to less specific binding of tau [65]. In addition, truncated forms of ApoE (present in the AD brain) facilitate the generation of inclusions that are NFT-like and comprise of high molecular weight phosphorylated neurofilaments and also phosphorylated tau [66]. The expression and activity of protein phosphatases 1,2A,2B and 5 (PP1, PP2A, PP2B, PP5) are altered in the AD brain $[28,67]$. Phosphoprotein phosphatases PP1, PP2A, PP2B, and PP5 dephosphorylates tau at variegated sites with PP2A being the key player in tau dephosphorylation with downregulated activity in the AD brain $[32,67,68]$. GSK-3 $\beta$ activation gives rise to increased accumulation of the inhibitor- 2 of protein phosphatase-2A $\left(\mathrm{I}_{2}{ }^{\mathrm{PP} 2 \mathrm{~A}}\right)$ and thereby decreases the activity of PP2A. The increase in $\mathrm{I}_{2}{ }^{\mathrm{PP} 2 \mathrm{~A}}$ inhibits PP2A activity and thereby hyperphosphorylates tau. Conversely, the downregulation of $\mathrm{I}_{2}{ }^{\mathrm{PP} 2 \mathrm{~A}}$ reinstates the activity of PP2A and attenuates the accumulation and phosphorylation of tau, inhibits GSK- $3 \beta$ through the activation of PKA, improves cognitive functions, and dendritic plasticity in studies conducted with human tau transgenic mice. Thus, with increased phosphorylation, decrease in the phosphatases activities can potentially induce hyperphosphorylation of tau [68-70]. 


\subsection{Connection between Tau Hyperphosphorylation and $A \beta$}

Tau protein phosphorylation has a strong connection with soluble $A \beta$ and this is well depicted in $\mathrm{AD}$ pathology. $\mathrm{A} \beta$ plaques disrupt neuronal excitability and thereby induce axonal bloating and neurite breakage, thus decreasing spine density [71]. There are accumulating scientific evidences that implicate the role of soluble $A \beta$ in the induction of phosphorylation of tau protein with GSK-3 $\beta$ identified as an important link between $A \beta$ and tau pathologies [72-77]. As $A \beta$ oligomers accumulate, they downstream Akt survival signaling pathways through inhibition of the phosphatidylinositol-3-kinase (PI-3K), likewise to GSK-3 $\beta$ activation and subsequent tau phosphorylation $[39,78]$. According to studies conducted in the AD brain by Jin et. al, natural A $\beta$ dimers at sub-nanomolar concentrations can instigate tau hyperphosphorylation at AD-specific sites. They can also disrupt the organization of microtubules and invoke neuritic dystrophy [73]. Studies have also demonstrated that following soluble $\mathrm{A} \beta$ oligomer treatment, hippocampal rat neurons resulted in incorrect localization of tau in the dendritic spines, thereby developing synaptic dysfunction [79]. In the somatodendritic compartment, investigation of localized early changes post AD treatment resulted in missorting of endogenous tau. The regions prevalent with missorted tau had local elevation of $\mathrm{Ca}^{2+}$, loss of microtubules, decreased mitochondrial density, and increased tau phosphorylation at AD-Tau specific site [80]. Lloret et al. has showed that A $\beta$ upregulates calcineurin 1 (RCAN1) expression while the enhanced RCAN1 levels facilitate increased tau phosphorylation through two different mechanisms. Firstly, RCAN1 impedes the activity of calcineurin, which takes part in tau dephosphorylation, and secondly, RCAN1 upregulates the activity of GSK-3 $\beta$. Therefore, overexpression of RCAN1 has a strong connection to AD neuropathology [81-83]. Porta et al. conducted studies in primary neurons that exhibited significant defiance to cell death under oxidative stress conditions that can be regressed by overexpression of RCAN1 in knockout mice [84]. A $\beta 42$ oligomers might induce stress in the endoplasmic reticulum where the released $\mathrm{Ca}^{2+}$ activates GSK-3 $\beta$ and subsequently enhances tau phosphorylation [85]. A $\beta$ species that are neurotoxic may bind to the cysteine-rich domain of the Wntbinding site and thus impede the canonical Wnt pathway, thereby further modulating the activity of GSK-3 $\beta$ [86].

\subsection{A $\beta$-Facilitated Increase in Tau phosphorylation in Animal Models}

Animal model studies investigating AD associated tau phosphorylation is instrumental in analyzing the underlying mechanisms and possible therapy options for the disease. Inhibition of GSK-3 $\beta$ is crucial in interrupting tau hyperphosphorylation and subsequent AD progression [87]. Several animal models have been studied over the last decade in order to further investigate the role of GSK-3 $\beta$ inhibitors on A $\beta$-mediated increase in tau hyperphosphorylation [88]. At larval stage, injection of $A \beta 42$ in the hindbrain ventricle of zebrafish embryos produced a decline in cognitive functions and enhanced GSK- $3 \beta$ site-specific tau phosphorylation. A potent GSK- $3 \beta$ inhibitor-Lithium Chloride was successful in reversing these specific behavioral and molecular effects [76]. Chabrier et al. has shown that double-transgenic mouse models that express low levels of arctic mutant $A \beta$ imitates the soluble $A \beta$ levels consequent with early $\mathrm{AD}$. Soluble $\mathrm{A} \beta$ promote the decline of cognitive functions and also influence tau progression significantly [89]. Studies conducted on triple transgenic ( $3 \mathrm{Xg}-\mathrm{AD})$ mice also reaffirmed that with increased aggregation of $\mathrm{A} \beta$ oligomers and pathological tau forms are exist togetherr [90]. It is understood that in $\mathrm{AD}, \mathrm{A} \beta$-induced tau pathology treatment with $\gamma$-secretase modulators also attenuates phosphorylated tau levels in animal models $[90,91]$. Specifically, protein kinase Akt phosphorylates GSK-3 $\beta$ at Ser9 and thereby instigates its inhibition in physiological conditions $[37,92]$. In the prevention of $A \beta$-induced long-term potentiation (LTP) inhibition, both caspase-3 and GSK-3 inhibitors were effective, thus underlying the potential of targeting GSK-3 in the prevention of cognitive impairment in AD. These models have been useful in predicting toxicological profiles in human AD patients, however further in vitro and in vivo studies are warranted for a more robust correlation. 


\section{Tau Mediated Neurotoxicity, Secretion and Inter-Cellular Transfer}

\subsection{Neurotoxicity from Tau}

Characterization of tau species accountable for $\mathrm{AD}$ pathogenesis and neurotoxicity is of significant interest in the field. Post-mortem studies conducted in AD patients have proven a strong correlation between the density of NFTs and respective cognitive impairments [93,94]. Pontecorvo et al. and Choi et al. have recently used tau Positron Emission Tomography (PET) tracers to conduct imaging studies involving selective tau species that mimic tau pathology and the progression of the disease as described by the Braak stages. Their findings suggested a strong, positive association between the decline of cognitive functions and tau aggregation, with implied harmful effects of insoluble tau $[95,96]$. Tau aggregation is further enhanced by the caspase cleavage at the $C$ terminus of tau [97]. Caspases (cysteine aspartate proteases) belong to a group of enzyme proteases that have instrumental roles in neuroinflammation and cell death [98]. Specific caspases known as executioner caspases facilitate apoptosis and nuclear fragmentation however more recent studies have revealed that caspases are activated in the brain of individuals suffering from AD [99-101]. Proapoptotic proteins in the brains of patients with $\mathrm{AD}$ are upregulated due to the caspase activity [102]. Furthermore, caspase-cleavage of tau and subsequent NFT formation has resulted in apoptosis in neurons of the AD brain in a number of recent investigations [102-105].

In human tau transfected HEK293 cell lines, NFT disrupted cell metabolism, like proteasome activity [106]. PHF-Tau obtained from the brains suffering from AD interacted with the 20S-subunit of this proteasome, thereby inhibiting the activity [107]. NFT-mediated decrease of the activity of this proteasome led to an aberrant protein accumulation, thus initiated a network of processes, ultimately leading to the death of neurons [108]. As observed in AD, the post-synaptic localization of pathologic Tau may be attributed to neurotoxicity as well. Dendritic tau was seen to communicate with proto-oncogene tyrosine-protein kinase Fyn in vivo, thereby facilitating $A \beta$ toxicity through Fyn/NMDA receptors (NR)/PSD95 coupling that are known for promoting excitotoxicity [16]. The level of native soluble tau and its physiological functions are attenuated by the pathological aggregation of Tau, thereby inducing resultant inimical effects. Therefore, loss of function of Tau results in the disruption of the network of microtubules, RNA/DNA integrity, axonal transport, cell signaling and impaired signaling of insulin the AD brain [22].

\subsection{Tau Secretion}

For a long time, it was accepted that irrespective of the neurotoxicity caused by tau, the marked increase in the levels of extracellular cerebrospinal fluid (CSF)-tau was the consequence of a passive release of pathologic Tau from dead neurons in AD patients. In healthy individuals, this passive secretion of pathologic Tau generated ghost tangles, even at low levels in CSF [109]. In recent times, more captivating observations have identified Tau secretion as more of an active process [110,111]. Accordingly, in the late stages of $\mathrm{AD}$, an end long decline in the levels of CSF-tau that were phosphorylated at the Thr181 site were seen to give rise to neuronal death [112]. Studies conducted in WT mice without any pre-existing neurodegeneration depicted physiological Tau secretion upon neuronal activity after the stimulation of $\alpha$-amino-3-hydroxy-5-methyl-4-isoxazolepropionic acid (AMPA) receptors [113,114]. In vitro, it was observed that the shortening at the Asp421 site and subsequent hyper phosphorylation of tau favors its secretion [115]. Exosome-associated tau had been identified in the CSF of AD patients $[116,117]$. The immune system can detect extracellular Tau and subsequently initiate an antigen-driven immune response. In a study conducted in the mouse model of Tauopathy rTg4510 with mutated P301L or WT, tau prompts strong humoral immune responses followed by anti-tau antibodie [118]. Another recent interesting study related to tau secretion makes use of the observation that trisomy of chromosome 21 (trisomy-21) neuronal secretomes are able to induce synaptic dysfunction through extracellular tau [119]. In a 2018 published study, this phenomena was investigated in human induced pluripotent stem cells (iPSCs) modeling trisomy 
21-related AD in murine model. Hu et al. showed that extracellular tau and related fragments with $(A \beta)$ in secretomes of human-derived iPSCs may be obtained (these iPSCs later differentiate into trisomy 21 neurons) and when these secretomes were injected into the rat brain it was seen to cause synaptic dysfunction. This secretome-induced synaptic dysfunction was measured in vivo by electrophysiology [120]. Figure 2 shows a schematic diagram of the process.

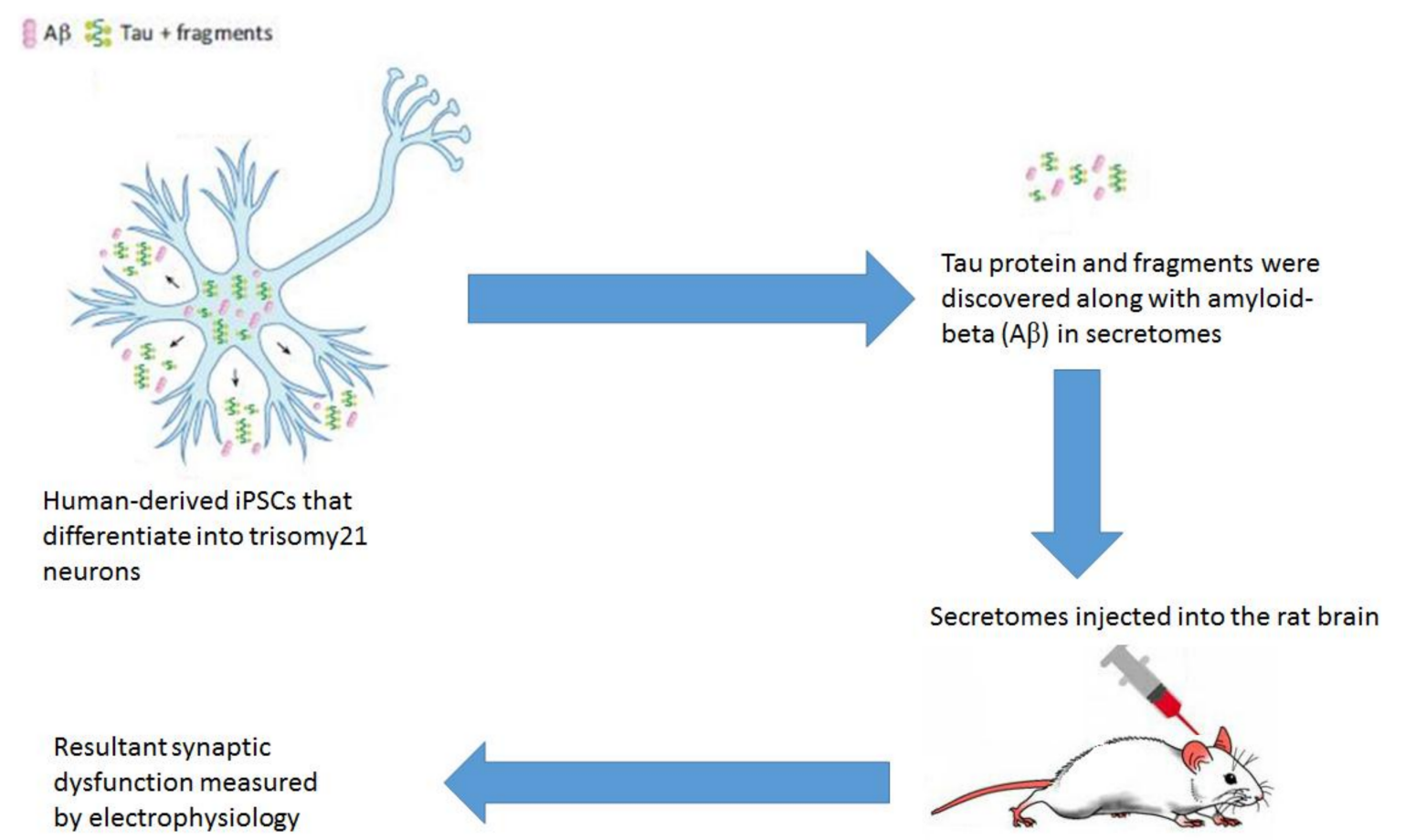

Figure 2. Synaptic dysfunction in rat model caused by secretomes from human derived iPSCs (Adapted from [121]).

In healthy individuals that are prone to recognizing pathological tau, circulating tau-specific antibodies were detected that can block in vitro tau aggregation through the cytosolic Fc receptor TRIM21 [122,123]. Thus, it is understood that in order to obtain successful tau-immunotherapy and attenuated $\mathrm{AD}$ progression, identification of the most immunogenic epitopes of tau and their respective interplay with the immune system is imperative [124].

\subsection{Tau Inter-Cellular Transfer}

A characteristic arrangement pattern of NFT lesions in AD progression is observed during the post-mortem of $\mathrm{AD}$ brains where lesions begin in the transentorhinal cortex, then subsequently progressing to the hippocampus and thus affecting the temporal cortex $[3,95,96,125]$. This distinct progression sequence suggested a strong link between the observed clinical symptoms and relevant affected areas, thereby underlining its pivotal role in synaptic dysfunction $[94,126,127]$. Experimental investigation of the propagation of Tau pathology was done in transgenic P301S mice where the findings suggested the enhanced NFT accumulation of NFT in wild-type (WT) mice occurred in a time- dependent manner. In the P301S mice model of tauopathy, trans-cellular generation of tau in a prion-like state was observed $[128,129]$. Tau seeding was observed as an early demonstration that are present in multiple regions of the brain regions and are linked to cognitive decline and subsequent disease progression [128]. Furthermore, insoluble Tau propagated more efficiently, showing no visible signs of neurodegeneration, thus advocating that the different molecular forms of tau exist for neurotoxicity and progression $[130,131]$. Trans-synaptic shift of wild type dephosphorylated tau can also be depicted using a lentiviral approach [132]. Finally, another study revealed the crucial role of 
microglial cells in the propagation of Tau through two models of tauopathy: (1) adeno- associated virus (AAV) expressing mutated P301L tau and (2) P301S mice [133]. The findings suggested that microglial cells successfully phagocytose the aggregated tau proteins and their resulting exosomal secretion is communicable to neurons. Thus, tau propagation is inhibited by the pharmacological exhaustion of microglial cells and exosomes; underlying the instrumental functions of microglia in tau propagation and postulate it as an effective target in attenuating $\mathrm{AD}$ progression.

\section{Role of Glial Cells in AD Pathology}

In addition to tau and $\mathrm{A} \beta$ pathologies, neuroinflammatory responses involving the accumulation of reactive astrocytes and microglia very close to the amyloid deposits is another histological feature of AD. Figure 3 shows a simple scheme of neurodegeneration resulting from glial cell activation. Astrocytes supply neuronal energy in the healthy brain, participate in synaptic function, instigate synaptic pruning, and modulates neutrotrophic factor release $[134,135]$. Throughout neuroinflammatory instances, however, Tumor Necrosis Factor (TNF $\alpha$ ), activated microglia-driven IL-1a, and C1q release favored the formation of reactive astrocytes known as A1. The ability to facilitate the formation of synapses and other normal functions are absent in A1 astrocytes, however, by secreting harmful factors, they induce neuronal death in the CNS [136,137]. In the AD brain, a greater proportion of $\mathrm{A} 1$ astrocytes were observed to produce complement protein $\mathrm{C} 3$, thereby asserting that this gain of toxic functions attributed to the harmful effects as there was a gradual loss of physiological properties as well [135]. In AD, morphological changes in astrocytes are instigated by neuronal tau misfolding, thereby cementing their inflammatory role through Glial fibrillary acidic protein (GFAP) regulation and subsequent secretion of pro-inflammatory factors $[138,139]$. In order to recreate the pathological features of astrocytic tau, transgenic mice were created that overexpressed the human tau gene [140]. Studies demonstrated that these mice develop Tau pathology in an age-dependent manner in astrocytes, and are implicated in focal neuron loss and also the disruption of the blood-brain-barrier. These phenomena further bolster the importance of reactive astrocytes in the variegated processes of different tauopathies.

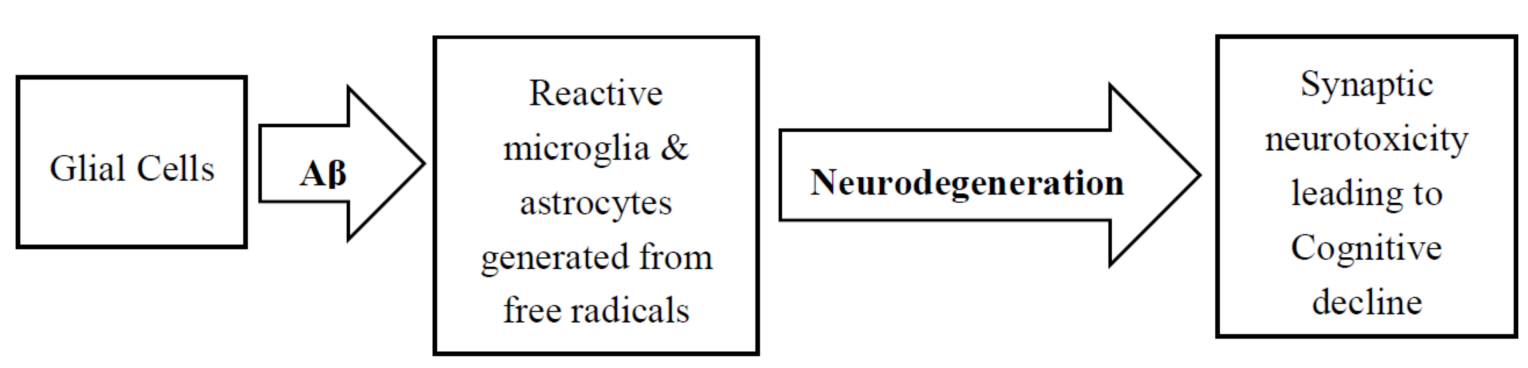

Figure 3. Neurodegeneration resulting from $A \beta$ activation of glial cells.

Microglia has an instrumental role in AD pathology and various other tauopathies. In-vivo two photon imaging of the microglial cells unveil very motile and diverged procedures, thus enabling a enterprising and recurrent investigation of the healthy brain [141]. Microglia is also implicated in variegated processes including synaptic plasticity, synapse elimination or neurogenesis [142,143]. In lights of $\mathrm{A} \beta$, the role of microglia on $\mathrm{AD}$ pathogenesis and progression was studied and reviewed extensively [144-146]. A complex, time-dependent effect on $A \beta$ pathology is observed in microglial cells where they release pro-inflammatory cytokines to facilitate the removal of $A \beta$ deposits implicated in the disease progression and overall neurotoxicity. During the disease course, longitudinal changes in the activation of microglia are measured using positron emission tomography (PET) scans. Among the patients that exhibited mild-cognitive impairment (MCI), in early stages an initial peak and another peak at a later stage of the disease were observed $[147,148]$. The two peaks of activation observed 
using PET scans might suggest a more biphasic role for microglia, however a larger cohort of patients would be required to validate this model.

Thus, the therapeutic avenues that target microglia require a solid, thorough comprehension along with better identification and classification of the disease in individual patients. The progression of AD might be influenced by locus coeruleus (LC), which is a brain structure that generates the anti-inflammatory neurotransmitter-norepinephrine (NE) $[4,149]$. Its degeneration promotes a disinhibiting effect favoring microglial activation and facilitates the inflammatory responses $[150,151]$. Moreover, AD pathogenesis is further promoted by the infiltration of the brain by peripheral innate immune subsets. In AD patients with cerebral parenchyma, neutrophil infiltration was attributed to the resulting damage in cognition and amplified Tau/amyloid pathology as observed in 3xTg-AD mice $[152,153]$. In addition, the phenotype of APP models could potentially be influenced by the incorporation of circulating monocytes by the chemoattractant protein CCL2 along with its respective cognate receptor, CCR2. In Tg2576 APP mice, the exclusion of CCR2 increased the microglial accumulation around the blood vessels through the incorporation of mononuclear phagocytes from the bone marrow and blood, thereby promoting perivascular deposits of A $\beta$ [154]. Studies conducted in CCR2 deficient APP/PS1 demonstrated detrimental effects on cognitive function $[154,155]$. Interestingly, the role of circulation monocytes in AD remains a highly debated issue since most the investigative experimental models included irradiation that compromised the blood-brain barrier [156]. Furthermore, in tau pathology, the innate immune system plays a pivotal role in the progression of the disease progression.

\section{Diagnostic Approaches for AD Using Tau-Imaging}

Gradual accumulation of tau in the brain has been widely identified as a biomarker of various neurodegenerative diseases that are collectively known as tauopathies, including $\mathrm{AD}$, frontotemporal dementias (FTD), Parkinson's disease (PD) and amyolateral sclerosis (ALS) [157-161]. Becket et al. suggested that measurable change in tau-which is also a cerebrospinal fluid (CSF) biomarker, occurs long before the clinical symptoms of AD emerge [162]. Other studies attempted CSF testing of phosphorylated-tau / $\beta$ ratio for the diagnosis of Alzheimer's disease in current clinical practice, although very limited clinical uncertainties were addressed [163]. Therefore, in AD, distinctive diagnosis continues to remain elusive since the symptoms and features heavily overlap with other types of dementia. Studies conducted by Inekci et al. found serum fragments of tau exhibiting an effective role in the differential diagnosis of AD [164]. However the range of accuracy for such diagnosis is limited and has a high propensity of change with different patients. Thus, there is a strong need for a better diagnostic tool in order to identify AD in early stages. In vivo, selective tau imaging can potentially facilitate an improved comprehension of the aggregation of tau in the AD brain, and potentially aid in the diagnosis and treatment outcomes $[165,166]$. Indeed, neuropathological studies have long demonstrated a strong correlation between changes in neurodegeneration, decline in cognitive function and the deposition of tau in patients with AD [167-169]. Therefore, selective tau imaging would eventuate the in-vivo investigation of said communication through the measurements of changes in tau deposit levels over the course of time.

Positron emission tomography (PET) is a noninvasive functional neuroimaging technique that allows us to design specific tracers and acquire neuronal images in small animals and humans [170]. PET imaging is suitable for examining molecular-level events, and therefore can be used for diagnosis, prognosis and recurrence of diseases. Recently, PET imaging has become very useful in current clinical practices to measure CSF A $\beta 42$ in the brain [171,172]. In order to implement PET as an effective biomarker of tau pathology, the acquired imaging measures from PET need to be directly associated with the tau deposition in the brain. Some ideal characteristics of the PET tracers include, but not limited to, high binding affinity for paired helical filament or PHF-tau, high binding selectivity for PHF-tau, high blood-brain barrier permeability and rapid clearance from normal brain tissue [170]. The recently developed PET tracers, such as $\left[{ }^{18} \mathrm{~F}\right]-\mathrm{AV}-1451$ (also known as T807), 
$\left[{ }^{11}\right.$ C]pyridinyl-butadienyl-benzothiazole 3 ([ $\left.{ }^{11} \mathrm{C}\right] \mathrm{PBB} 3$ ) and THK-5117, are able to successfully bind to the aggregated tau in neurofibrillary tangles [173-181], and can noninvasively measure the degree and extent of tau pathology in the brain.

Two of the well-known, recently developed tau-selective PET tracers are $\left[{ }^{18} \mathrm{~F}\right] \mathrm{T} 807$ and $\left[{ }^{18} \mathrm{~F}\right] \mathrm{T} 808[173,182] .\left[{ }^{18} \mathrm{~F}\right]-\mathrm{T} 807$ is a F-18-labeled small molecule demonstrating high selective binding and affinity to tau protein aggregates [183]. Chien et. al. demonstrated the first successful $\left[{ }^{18} \mathrm{~F}\right] \mathrm{T} 807$ retention of PHF-tau in the AD brain, as well as the association of $\left[{ }^{18} \mathrm{~F}\right] \mathrm{T} 807$ with increased disease severity [173]. Further, preliminary analyses have demonstrated that $\left[{ }^{18} \mathrm{~F}\right]-\mathrm{T} 807$ binding is amplified in neocortical areas of AD patients when compared with patients with normal cognitive function [184-186]. Moreover, $\left[{ }^{18} \mathrm{~F}\right]-\mathrm{T} 807$ binding at the cortical regions in AD could provide efficient diagnosis for staging of AD [187-190]. Another recent preclinical study investigating $\left[{ }^{18} \mathrm{~F}\right]-\mathrm{T} 808$ reported that compared to healthy controls, patients with greater probability of AD exhibited regional distinct areas of uptake in the gray matter [182]. This study concluded that compared to $\left[{ }^{18} \mathrm{~F}\right] \mathrm{T} 807$, $\left[{ }^{18} \mathrm{~F}\right] \mathrm{T} 808$ tracer exhibited more rapid tracer distribution across the brain as well as more rapid clearance from healthy brain tissue.

Another PET tracer, $\left[{ }^{11} \mathrm{C}\right] \mathrm{PBB} 3$, allows detection of tau deposits in tauopathies, including AD, progressive supranuclear palsy (PSP) and corticobasal degeneration (CBD) [175]. This particular PET tracer has been constructed with adequate radioactivity and higher quality in clinical studies, and has shown the ability to differentiate between $\mathrm{AD}$ patients and healthy individuals [175]. A recent study explored the associations among clinical symptoms, regional tau and $A \beta$ deposition assessed by PET imaging with $\left[{ }^{11} \mathrm{C}\right] \mathrm{PBB} 3$ and $\left[{ }^{11} \mathrm{C}\right]$ Pittsburgh compound-B (PiB) in AD, MCI due to AD and healthy individuals, and identified significant positive correlation between tau accumulation with $A \beta$ pathology in all subjects, as well as significant correlation with tau burden in the healthy individuals. [191]. Further, $\left.{ }^{[1} \mathrm{C}\right] \mathrm{PBB} 3$ holding in the hippocampal region of AD patients verifies its binding ability to neurofibrillary tangles (NFTs). Additional investigation using PET studies with $\left[{ }^{11} \mathrm{C}\right]$ PBB3 tracer is required to validate its clinical usefulness in other types of tauopathies.

Other notable PET tracers include $\left[{ }^{18} \mathrm{~F}\right] \mathrm{THK}-523,\left[{ }^{18} \mathrm{~F}\right] \mathrm{THK}-5105$ and $\left[{ }^{18} \mathrm{~F}\right] \mathrm{THK}-5117$ that have exhibited high binding selectivity to tau over $\mathrm{A} \beta$ in AD brain [192,193]. A recent study by Okamura et al. demonstrated that $\left[{ }^{18} \mathrm{~F}\right] \mathrm{THK}-5105$ tracer successfully bound in sites subjected to tau deposition in the AD [176], while another study showed that $\left[{ }^{18} \mathrm{~F}\right] \mathrm{THK}-523$ tracer failed to demonstrate such tau deposition in human brain [181]. Further, compared to $\left[{ }^{18} \mathrm{~F}\right] \mathrm{THK}-5105$, $\left[{ }^{18} \mathrm{~F}\right] \mathrm{THK}-5117$ tracer showed greater signal-to-background ratio in a PET imaging study by Shah et al. [181].These studies suggest that understanding the underlying mechanisms of tau dysregulation and incorporating them as disease-specific markers could facilitate the diagnosis of preclinical $\mathrm{AD}$, and might potentially lead to therapeutic treatments. Thus, for monitoring the efficacy of anti-tau therapy in AD, selective tau imaging might be the key player with instrumental roles in diagnostic, prognostic, and progression biomarker upon clinical validation.

\section{Immune Responses and Neuroprotection in Tau Pathology: Therapeutic Opportunities}

\subsection{Immune Responses and Neuroinflammation}

Recent studies have unveiled that the incidence of Tau pathology is attributed to instigate the activation of microglia and astrocytes. Patients suffering from frontotemporal dementia (FTD) who have P301S mutation depict CD68 positive microglial cells that are activated around neurons that pertain hyperphosphorylated Tau [194]. During the regulation of cyclooxygenase-2(Cox2) and Interleukin-1 $\beta$ (IL1 $\beta)$, incidence of a strong, neuroinflammatory response was observed. During microglial activation, GFAP astrocytes that were reactive are also observed in Pick's disease [195].Thus, tau pathology facilitates the development of neuroinflammation. In various transgenic tauopathy models, neuroinflammatory changes in pathology and age-dependent microglial activation was seen in relevant CNS structures [138,196-198]. Activation of the innate immune response prior to the formation 
of hippocampal NFT implicates the involvement of soluble Tau species [198]. Recent study findings have emphasized that through the activation of inflammasome, pathological Tau could enhance the secretion of IL-1 $\beta$ [199]. Strategies that modulate Tau pathology impact immune response while the neuroinflammatory responses have been observed to impact Tau pathogenesis. Both Tau misfolding and neuroinflammatory response influences the impairment of behavior through loss of synaptic and neuronal integrity, henceforth facilitating the progression of pathological changes [200,201]. Microglia is involved in all the different steps occuring in the aggregation of tau, its propagation and subsequent alternation of synapse, and phosphorylation, rendering itself as an important therapeutic target in modulating AD pathogenesis and other related tauopathies. Adult neurogenesis can be induced by glial cells through the production of a potent inflammatory reaction that attenuates neuronal differentiation or progenitor proliferation [202]. Thus, existence of a hazardous loop between tau pathology, inflammation, and neurogenesis is evident and therefore, neuroprotective/therapeutic endeavors need to be carefully guided for $\mathrm{AD}$ attenuation.

\subsection{Neuroprotection against $A D-T a u$}

Whether the hyperphosphorylation of tau results in a toxic gain or systemic loss of function is of much debate in the field for a long time. Previously, it was thought that NFT and A $\beta$ plaques resulted in the secretion of glutamate in the cortical region that led to excitotoxicity $[203,204]$. There is substantial evidence suggesting that the accumulation of $A \beta$ is the primary causative process in $A D$ [205]. The reticence of $A \beta$ production, attenuation of soluble $A \beta$, and amplification of $A \beta$ removal posit promising approaches for decreasing $A \beta$ levels $[206,207]$. The strategies for best therapeutic target procurement involve inhibition of both $A \beta$ plaque buildup, and tau hyperphosphorylation. Using non-selective $\gamma$-secretase inhibitors, potential inhibition of $A \beta$ and subsequent decline in moderate AD were achieved in Phase III clinical trials [208,209].Ittner et al. has previously demonstrated a unique mechanism through which the phosphorylation of Threonine 205, a specific residue of tau that is of significance for protection against $A \beta$ induced excitotoxicity [210]. The conclusions from this study suggested that phosphorylation of tau has neuroprotective functions in certain cases. The role of tau hyperphosphorylation has been extensively discussed earlier and it is imperative that the inhibition of tau hyperphosphorylation would elucidate neuroprotective effects against AD. GSK-3 $\beta$ hyphosphorylates tau and thus, there is a growing interest in employing GSK-3 $\beta$ inhibitors as neuroprotective agents [211]. Agents like valproate, neuroglobin and lithium have established efficient GSK-3 $\beta$ inhibition and thus showed promise for reducing AD progression [212-214]. A large number of kinases (e.g. Cdk5, ERK) phosphorylates tau and thus posits as potential small molecule targets in AD pathology [215]. Pedersen et al has shown high clinical efficacy in several in vivo AD model studies using immunotherapy against hyperphosphorylated tau [216]. Another lucrative therapy suggested through studies conducted by Kontsekova et al demonstrated effectiveness of the vaccine AAD-vac1 in targeting tau [217]. Neuroprotective approaches resulting from studies conducted with mictrobules instill the role of small molecules, which can potentially aid in the stabilization of microtubules as well as in the prevention of cytoskeletal disruption and A $\beta$-induced toxicity [218]. Histone deacetylase protein Sirtuin 6 (SIRT6) has been implicated in DNA repair and neurodegeneration where the lack of SIRT6 correlates with increased phosphorylation of tau [12,219].Furthermore, SIRT6 depletion in the AD brain results in increased GSK-3 $\beta$ activity, tau hyperphosphorylation, and subsequent neurodegeneration [220]. Thus, therapies targeting the increased expression of SIRT6 could present an effective solution towards attenuating $\mathrm{AD}$. pathogenesis.

\section{Conclusions}

As AD research progresses, it is becoming evidently clear to many scientists that the role of tau in neurodegeneration is of utmost importance as we continue to solve the problems of science. The role of tau hyperphosphorylation in $\mathrm{AD}$ and its subsequent detrimental effects on the cognitive 
function and aging-related processes posit a great challenge towards the field of neuroscience. Several strategies have been implemented to combat this issue including small molecule GSK-3 $\beta$ inhibitors, phosphoprotein phosphatases, and tau immunotherapy. However, the efficacy of these methods yet remains to be validated in greater $\mathrm{AD}$ population. Tau therapies involving the immune system have also been proposed as a promising avenue against cognitive decline. Accurate diagnosis of AD remains a long-standing problem, although recent advances in tau-imaging seek to provide a potential solution. Much success has been achieved in recent times with in vivo PET imaging of tau and its implication in the diagnosis of early-stage AD. The polychromatic roles of tau have the propensity to amplify further beyond the current knowledge in the field as time progresses. Better diagnosis would eventually lead towards the development of efficient therapeutic targets in AD pathology. However, more time and resources are required to further understand the processes involved in the disease progression. Future studies may possibly transpire strong therapeutic targets and thereby design effective drugs to attenuate, alleviate or possibly even cure AD.

Author Contributions: R.I.K., S.S.R.N., and B.R wrote, reviewed and edited the manuscript. All authors contributed equally to this work.

Funding: This research received no external funding.

Conflicts of Interest: The authors declare no conflict of interest.

\section{References}

1. Federico, C.; Gil, L.; Bruno, F.; D’Amico, A.G.; D’Agata, V.; Saccone, S. Phosphorylated nucleolar Tau protein is related to the neuronal in vitro differentiation. Gene 2018, 664, 1-11. [CrossRef] [PubMed]

2. Morris, M.; Maeda, S.; Vossel, K.; Mucke, L. The Many Faces of Tau. Neuron 2011, 70, 410-426. [CrossRef] [PubMed]

3. Braak, H.; Braak, E. Neuropathological stageing of Alzheimer-related changes. Acta Neuropathol. 1991, 82, 239-259. [CrossRef] [PubMed]

4. Šimić, G.; Babić Leko, M.; Wray, S.; Harrington, C.R.; Delalle, I.; Jovanov-Milošević, N.; Bažadona, D.; Buée, L.; de Silva, R.; Di Giovanni, G.; et al. Monoaminergic neuropathology in Alzheimer's disease. Prog. Neurobiol. 2017, 151, 101-138. [CrossRef] [PubMed]

5. Šimić, G.; Babić Leko, M.; Wray, S.; Harrington, C.; Delalle, I.; Jovanov-Milošević, N.; Bažadona, D.; Buée, L.; de Silva, R.; Di Giovanni, G.; Wischik, C.; Hof, P. Tau Protein Hyperphosphorylation and Aggregation in Alzheimer's Disease and Other Tauopathies, and Possible Neuroprotective Strategies. Biomolecules 2016, 6, 6 . [CrossRef] [PubMed]

6. Wischik, C.M.; Harrington, C.R.; Storey, J.M.D. Tau-aggregation inhibitor therapy for Alzheimer's disease. Biochem. Pharmacol. 2014, 88, 529-539. [CrossRef] [PubMed]

7. Binder, L.I.; Frankfurter, A.; Rebhun, L.I. The distribution of tau in the mammalian central nervous system. J. Cell Biol. 1985, 101, 1371-1378. [CrossRef] [PubMed]

8. Choi, M.C.; Raviv, U.; Miller, H.P.; Gaylord, M.R.; Kiris, E.; Ventimiglia, D.; Needleman, D.J.; Kim, M.W.; Wilson, L.; Feinstein, S.C.; et al. Human Microtubule-Associated-Protein Tau Regulates the Number of Protofilaments in Microtubules: A Synchrotron X-Ray Scattering Study. Biophys. J. 2009, 97, 519-527. [CrossRef] [PubMed]

9. Wang, Y.; Mandelkow, E. Tau in physiology and pathology. Nat. Rev. Neurosci. 2016, 17, 22-35. [CrossRef] [PubMed]

10. Violet, M.; Delattre, L.; Tardivel, M.; Sultan, A.; Chauderlier, A.; Caillierez, R.; Talahari, S.; Nesslany, F.; Lefebvre, B.; Bonnefoy, E.; et al. A major role for Tau in neuronal DNA and RNA protection in vivo under physiological and hyperthermic conditions. Front. Cell. Neurosci. 2014, 8, 84. [CrossRef] [PubMed]

11. Sultan, A.; Nesslany, F.; Violet, M.; Bégard, S.; Loyens, A.; Talahari, S.; Mansuroglu, Z.; Marzin, D.; Sergeant, N.; Humez, S.; et al. Nuclear Tau, a key player in neuronal DNA protection. J. Biol. Chem. 2011, 286, 4566-4575. [CrossRef] [PubMed] 
12. Kaluski, S.; Portillo, M.; Besnard, A.; Mostoslavsky, R.; Sahay, A.; Correspondence, D.T.; Stein, D.; Einav, M.; Zhong, L.; Ueberham, U.; et al. Neuroprotective Functions for the Histone Deacetylase SIRT6 Cell Reports Report Neuroprotective Functions for the Histone Deacetylase SIRT6. Cell Rep. 2017, 18, 3052-3062. [CrossRef] [PubMed]

13. Kovacs, G.G.; Ferrer, I.; Grinberg, L.T.; Alafuzoff, I.; Attems, J.; Budka, H.; Cairns, N.J.; Crary, J.F.; Duyckaerts, C.; Ghetti, B.; et al. Aging-related tau astrogliopathy (ARTAG): harmonized evaluation strategy. Acta Neuropathol. 2016, 131, 87-102. [CrossRef] [PubMed]

14. Crary, J.F.; Trojanowski, J.Q.; Schneider, J.A.; Abisambra, J.F.; Abner, E.L.; Alafuzoff, I.; Arnold, S.E.; Attems, J.; Beach, T.G.; Bigio, E.H.; et al. Primary age-related tauopathy (PART): A common pathology associated with human aging. Acta Neuropathol. 2014, 128, 755-766. [CrossRef] [PubMed]

15. Frandemiche, M.L.; De Seranno, S.; Rush, T.; Borel, E.; Elie, A.; Arnal, I.; Lante, F.; Buisson, A. Activity-Dependent Tau Protein Translocation to Excitatory Synapse Is Disrupted by Exposure to Amyloid-Beta Oligomers. J. Neurosci. 2014, 34, 6084-6097. [CrossRef] [PubMed]

16. Ittner, L.M.; Ke, Y.D.; Delerue, F.; Bi, M.; Gladbach, A.; van Eersel, J.; Wölfing, H.; Chieng, B.C.; Christie, M.J.; Napier, I.A.; et al. Dendritic Function of Tau Mediates Amyloid- $\beta$ Toxicity in Alzheimer's Disease Mouse Models. Cell 2010, 142, 387-397. [CrossRef] [PubMed]

17. Kimura, T.; Whitcomb, D.J.; Jo, J.; Regan, P.; Piers, T.; Heo, S.; Brown, C.; Hashikawa, T.; Murayama, M.; Seok, H.; et al. Microtubule-associated protein tau is essential for long-term depression in the hippocampus. Philos. Trans. R. Soc. B Biol. Sci. 2013, 369, 20130144. [CrossRef] [PubMed]

18. Lee, G.; Newman, S.T.; Gard, D.L.; Band, H.; Panchamoorthy, G. Tau interacts with src-family non-receptor tyrosine kinases. J. Cell Sci. 1998, 111, 3167-3177. [PubMed]

19. Tai, H.-C.; Wang, B.Y.; Serrano-Pozo, A.; Frosch, M.P.; Spires-Jones, T.L.; Hyman, B.T. Frequent and symmetric deposition of misfolded tau oligomers within presynaptic and postsynaptic terminals in Alzheimer's disease. Acta Neuropathol. Commun. 2014, 2, 146. [CrossRef] [PubMed]

20. Mansuroglu, Z.; Benhelli-Mokrani, H.; Marcato, V.; Sultan, A.; Violet, M.; Chauderlier, A.; Delattre, L.; Loyens, A.; Talahari, S.; Bégard, S.; et al. Loss of Tau protein affects the structure, transcription and repair of neuronal pericentromeric heterochromatin. Sci. Rep. 2016, 6, 33047. [CrossRef] [PubMed]

21. Violet, M.; Chauderlier, A.; Delattre, L.; Tardivel, M.; Chouala, M.S.; Sultan, A.; Marciniak, E.; Humez, S.; Binder, L.; Kayed, R.; et al. Prefibrillar Tau oligomers alter the nucleic acid protective function of Tau in hippocampal neurons in vivo. Neurobiol. Dis. 2015, 82, 540-551. [CrossRef] [PubMed]

22. Marciniak, E.; Leboucher, A.; Caron, E.; Ahmed, T.; Tailleux, A.; Dumont, J.; Issad, T.; Gerhardt, E.; Pagesy, P.; Vileno, M.; et al. Tau deletion promotes brain insulin resistance. J. Exp. Med. 2017, 214, 2257-2269. [CrossRef] [PubMed]

23. Arendt, T.; Stieler, J.T.; Holzer, M. Tau and tauopathies. Brain Res. Bull. 2016, 126, 238-292. [CrossRef] [PubMed]

24. Guo, T.; Noble, W.; Hanger, D.P. Roles of tau protein in health and disease. Acta Neuropathol. 2017, 133, 665-704. [CrossRef] [PubMed]

25. Morris, M.; Knudsen, G.M.; Maeda, S.; Trinidad, J.C.; Ioanoviciu, A.; Burlingame, A.L.; Mucke, L. Tau post-translational modifications in wild-type and human amyloid precursor protein transgenic mice. Nat. Neurosci. 2015, 18, 1183-1189. [CrossRef] [PubMed]

26. Hanger, D.P.; Seereeram, A.; Noble, W. Mediators of tau phosphorylation in the pathogenesis of Alzheimer's disease. Expert Rev. Neurother. 2009, 9, 1647-1666. [CrossRef] [PubMed]

27. Sergeant, N.; Bretteville, A.; Hamdane, M.; Caillet-Boudin, M.-L.; Grognet, P.; Bombois, S.; Blum, D.; Delacourte, A.; Pasquier, F.; Vanmechelen, E.; et al. Biochemistry of Tau in Alzheimer's disease and related neurological disorders. Expert Rev. Proteomics 2008, 5, 207-224. [CrossRef] [PubMed]

28. Martin, L.; Latypova, X.; Wilson, C.M.; Magnaudeix, A.; Perrin, M.-L.; Yardin, C.; Terro, F. Tau protein kinases: Involvement in Alzheimer's disease. Ageing Res. Rev. 2013, 12, 289-309. [CrossRef] [PubMed]

29. Papon, M.-A.; El Khoury, N.B.; Marcouiller, F.; Julien, C.; Morin, F.; Bretteville, A.; Petry, F.R.; Gaudreau, S.; Amrani, A.; Mathews, P.M.; et al. Deregulation of protein phosphatase 2A and hyperphosphorylation of $\tau$ protein following onset of diabetes in NOD mice. Diabetes 2013, 62, 609-617. [CrossRef] [PubMed] 
30. Zheng-Fischhöfer, Q.; Biernat, J.; Mandelkow, E.M.; Illenberger, S.; Godemann, R.; Mandelkow, E. Sequential phosphorylation of Tau by glycogen synthase kinase-3beta and protein kinase A at Thr212 and Ser214 generates the Alzheimer-specific epitope of antibody AT100 and requires a paired-helical-filament-like conformation. Eur. J. Biochem. 1998, 252, 542-552. [CrossRef] [PubMed]

31. Malia, T.J.; Teplyakov, A.; Ernst, R.; Wu, S.-J.; Lacy, E.R.; Liu, X.; Vandermeeren, M.; Mercken, M.; Luo, J.; Sweet, R.W.; Gilliland, G.L. Epitope mapping and structural basis for the recognition of phosphorylated tau by the anti-tau antibody AT8. Proteins Struct. Funct. Bioinforma. 2016, 84, 427-434. [CrossRef] [PubMed]

32. Wang, J.-Z.; Xia, Y.-Y.; Grundke-Iqbal, I.; Iqbal, K. Abnormal Hyperphosphorylation of Tau: Sites, Regulation, and Molecular Mechanism of Neurofibrillary Degeneration. J. Alzheimer's Dis. 2012, 33, S123-S139. [CrossRef] [PubMed]

33. Iqbal, K.; Liu, F.; Gong, C.-X.; Alonso, A.d.C.; Grundke-Iqbal, I. Mechanisms of tau-induced neurodegeneration. Acta Neuropathol. 2009, 118, 53-69. [CrossRef] [PubMed]

34. Simic, G.; Stanic, G.; Mladinov, M.; Jovanov-Milosevic, N.; Kostovic, I.; Hof, P.R. Does Alzheimer's disease begin in the brainstem? Neuropathol. Appl. Neurobiol. 2009, 35, 532-554. [CrossRef] [PubMed]

35. Perluigi, M.; Barone, E.; Di Domenico, F.; Butterfield, D.A. Aberrant protein phosphorylation in Alzheimer disease brain disturbs pro-survival and cell death pathways. Biochim. Biophys. Acta-Mol. Basis Dis. 2016, 1862, 1871-1882. [CrossRef] [PubMed]

36. Hooper, C.; Killick, R.; Lovestone, S. The GSK3 hypothesis of Alzheimer's disease. J. Neurochem. 2008, 104, 1433-1439. [CrossRef] [PubMed]

37. Lei, P.; Ayton, S.; Bush, A.I.; Adlard, P.A. GSK-3 in Neurodegenerative Diseases. Int. J. Alzheimers. Dis. 2011, 2011, 1-9. [CrossRef] [PubMed]

38. Jembrek, M.; Babić, M.; Pivac, N.; Hof, P.; Šimić, G. Hyperphosphorylation of tau by GSK-3 $\beta$ in Alzheimer's disease: The interaction of $\mathrm{A} \beta$ and sphingolipid mediators as a therapeutic target. Transl. Neurosci. 2013, 4, 466-476. [CrossRef]

39. Takashima, A.; Noguchi, K.; Michel, G.; Mercken, M.; Hoshi, M.; Ishiguro, K.; Imahori, K. Exposure of rat hippocampal neurons to amyloid beta peptide (25-35) induces the inactivation of phosphatidyl inositol-3 kinase and the activation of tau protein kinase I/glycogen synthase kinase-3 beta. Neurosci. Lett. 1996, 203, 33-36. [CrossRef]

40. Bijur, G.N.; Jope, R.S. Proapoptotic Stimuli Induce Nuclear Accumulation of Glycogen Synthase Kinase- $3 \beta$. J. Biol. Chem. 2001, 276, 37436-37442. [CrossRef] [PubMed]

41. Lace, G.; Savva, G.M.; Forster, G.; de Silva, R.; Brayne, C.; Matthews, F.E.; Barclay, J.J.; Dakin, L.; Ince, P.G.; Wharton, S.B. MRC-CFAS Hippocampal tau pathology is related to neuroanatomical connections: An ageing population-based study. Brain 2009, 132, 1324-1334. [CrossRef] [PubMed]

42. Rüb, U.; Stratmann, K.; Heinsen, H.; Del Turco, D.; Ghebremedhin, E.; Seidel, K.; den Dunnen, W.; Korf, H.-W. Hierarchical Distribution of the Tau Cytoskeletal Pathology in the Thalamus of Alzheimer's Disease Patients. J. Alzheimer's Dis. 2015, 49, 905-915. [CrossRef] [PubMed]

43. Braak, H.; Alafuzoff, I.; Arzberger, T.; Kretzschmar, H.; Del Tredici, K. Staging of Alzheimer disease-associated neurofibrillary pathology using paraffin sections and immunocytochemistry. Acta Neuropathol. 2006, 112, 389-404. [CrossRef] [PubMed]

44. Nelson, P.T.; Alafuzoff, I.; Bigio, E.H.; Bouras, C.; Braak, H.; Cairns, N.J.; Castellani, R.J.; Crain, B.J.; Davies, P.; Tredici, K.; et al. Correlation of Alzheimer Disease Neuropathologic Changes With Cognitive Status: A Review of the Literature. J. Neuropathol. Exp. Neurol. 2012, 71, 362-381. [CrossRef] [PubMed]

45. Wang, J.-Z.; Grundke-Iqbal, I.; Iqbal, K. Kinases and phosphatases and tau sites involved in Alzheimer neurofibrillary degeneration. Eur. J. Neurosci. 2007, 25, 59-68. [CrossRef] [PubMed]

46. Scott, C.W.; Spreen, R.C.; Herman, J.L.; Chow, F.P.; Davison, M.D.; Young, J.; Caputo, C.B. Phosphorylation of recombinant tau by cAMP-dependent protein kinase. Identification of phosphorylation sites and effect on microtubule assembly. J. Biol. Chem. 1993, 268, 1166-1173. [PubMed]

47. Litersky, J.M.; Johnson, G.V.; Jakes, R.; Goedert, M.; Lee, M.; Seubert, P. Tau protein is phosphorylated by cyclic AMP-dependent protein kinase and calcium/calmodulin-dependent protein kinase II within its microtubule-binding domains at Ser-262 and Ser-356. Biochem. J. 1996, 316, 655-660. [CrossRef] [PubMed]

48. Sironi, J.J.; Yen, S.H.; Gondal, J.A.; Wu, Q.; Grundke-Iqbal, I.; Iqbal, K. Ser-262 in human recombinant tau protein is a markedly more favorable site for phosphorylation by CaMKII than PKA or PhK. FEBS Lett. 1998, 436, 471-475. [CrossRef] 
49. Schneider, A.; Biernat, J.; von Bergen, M.; Mandelkow, E.; Mandelkow, E.-M. Phosphorylation that Detaches Tau Protein from Microtubules (Ser262, Ser214) Also Protects It against Aggregation into Alzheimer Paired Helical Filaments. Biochemistry 1999, 38, 3549-3558. [CrossRef] [PubMed]

50. Wang, J.; Wang, X.; Liu, R.; Wang, Q.; Grundke-Iqbal, I.; Iqbal, K. In vitro analysis of tau phosphorylation sites and its biological activity. Chinese Med. Sci. J. Chung-kuo i hsueh k'o hsueh tsa chih 2002, 17, 13-16.

51. Ksiezak-Reding, H.; Pyo, H.K.; Feinstein, B.; Pasinetti, G.M. Akt/PKB kinase phosphorylates separately Thr212 and Ser214 of tau protein in vitro. Biochim. Biophys. Acta 2003, 1639, 159-168. [CrossRef] [PubMed]

52. Taniguchi, T.; Kawamata, T.; Mukai, H.; Hasegawa, H.; Isagawa, T.; Yasuda, M.; Hashimoto, T.; Terashima, A.; Nakai, M.; Ono, Y.; Tanaka, C.; Tanaka, C. Phosphorylation of Tau Is Regulated by PKN. J. Biol. Chem. 2001, 276, 10025-10031. [CrossRef] [PubMed]

53. Thornton, C.; Bright, N.J.; Sastre, M.; Muckett, P.J.; Carling, D. AMP-activated protein kinase (AMPK) is a tau kinase, activated in response to amyloid $\beta$-peptide exposure. Biochem. J. 2011, 434, 503-512. [CrossRef] [PubMed]

54. Vingtdeux, V.; Davies, P.; Dickson, D.W.; Marambaud, P. AMPK is abnormally activated in tangle- and pre-tangle-bearing neurons in Alzheimer's disease and other tauopathies. Acta Neuropathol. 2011, 121, 337-349. [CrossRef] [PubMed]

55. Pei, J.J.; Grundke-Iqbal, I.; Iqbal, K.; Bogdanovic, N.; Winblad, B.; Cowburn, R.F. Accumulation of cyclin-dependent kinase 5 ( $\mathrm{cdk} 5)$ in neurons with early stages of Alzheimer's disease neurofibrillary degeneration. Brain Res. 1998, 797, 267-277. [CrossRef]

56. Liu, F.; Iqbal, K.; Grundke-Iqbal, I.; Gong, C.-X. Involvement of aberrant glycosylation in phosphorylation of tau by cdk5 and GSK-3beta. FEBS Lett. 2002, 530, 209-214. [CrossRef]

57. Wang, J.-Z.; Liu, F. Microtubule-associated protein tau in development, degeneration and protection of neurons. Prog. Neurobiol. 2008, 85, 148-175. [CrossRef] [PubMed]

58. Johnson, G.V.; Hartigan, J.A. Tau protein in normal and Alzheimer's disease brain: an update. J. Alzheimers. Dis. 1999, 1, 329-351. [CrossRef] [PubMed]

59. Godemann, R.; Biernat, J.; Mandelkow, E.; Mandelkow, E.-M. Phosphorylation of tau protein by recombinant GSK-3 $\beta$ : Pronounced phosphorylation at select Ser/Thr-Pro motifs but no phosphorylation at Ser262 in the repeat domain. FEBS Lett. 1999, 454, 157-164. [CrossRef]

60. Wang, J.Z.; Wu, Q.; Smith, A.; Grundke-Iqbal, I.; Iqbal, K. Tau is phosphorylated by GSK-3 at several sites found in Alzheimer disease and its biological activity markedly inhibited only after it is prephosphorylated by A-kinase. FEBS Lett. 1998, 436, 28-34. [CrossRef]

61. Berger, Z.; Roder, H.; Hanna, A.; Carlson, A.; Rangachari, V.; Yue, M.; Wszolek, Z.; Ashe, K.; Knight, J.; Dickson, D.; et al. Accumulation of Pathological Tau Species and Memory Loss in a Conditional Model of Tauopathy. J. Neurosci. 2007, 27, 3650-3662. [CrossRef] [PubMed]

62. Tepper, K.; Biernat, J.; Kumar, S.; Wegmann, S.; Timm, T.; Hübschmann, S.; Redecke, L.; Mandelkow, E.-M.; Müller, D.J.; Mandelkow, E. Oligomer Formation of Tau Protein Hyperphosphorylated in Cells. J. Biol. Chem. 2014, 289, 34389-34407. [CrossRef] [PubMed]

63. Alonso, A.d.C.; Zaidi, T.; Novak, M.; Grundke-Iqbal, I.; Iqbal, K. Hyperphosphorylation induces self-assembly of into tangles of paired helical filaments/straight filaments. Proc. Natl. Acad. Sci. USA 2001, 98, 6923-6928. [CrossRef] [PubMed]

64. Hoe, H.-S.; Freeman, J.; Rebeck, G.W. Apolipoprotein E decreases tau kinases and phospho-tau levels in primary neurons. Mol. Neurodegener. 2006, 1, 18. [CrossRef] [PubMed]

65. Small, S.A.; Duff, K. Linking Abeta and tau in late-onset Alzheimer's disease: A dual pathway hypothesis. Neuron 2008, 60, 534-542. [CrossRef] [PubMed]

66. Huang, Y.; Liu, X.Q.; Wyss-Coray, T.; Brecht, W.J.; Sanan, D.A.; Mahley, R.W. Apolipoprotein E fragments present in Alzheimer's disease brains induce neurofibrillary tangle-like intracellular inclusions in neurons. Proc. Natl. Acad. Sci. USA 2001, 98, 8838-8843. [CrossRef] [PubMed]

67. Voronkov, M.; Braithwaite, S.P.; Stock, J.B. Phosphoprotein phosphatase 2A: A novel druggable target for Alzheimer's disease. Future Med. Chem. 2011, 3, 821-833. [CrossRef] [PubMed]

68. Zhou, X.-W.; Gustafsson, J.-Å.; Tanila, H.; Bjorkdahl, C.; Liu, R.; Winblad, B.; Pei, J.-J. Tau hyperphosphorylation correlates with reduced methylation of protein phosphatase 2A. Neurobiol. Dis. 2008, 31, 386-394. [CrossRef] [PubMed] 
69. Zhang, X.; Wang, J.; Xing, Y.; Gong, L.; Li, H.; Wu, Z.; Li, Y.; Wang, J.; Wang, Y.; Dong, L.; Li, S. Effects of ginsenoside $\mathrm{Rg} 1$ or $17 \beta$-estradiol on a cognitively impaired, ovariectomized rat model of Alzheimer's disease. Neuroscience 2012, 220, 191-200. [CrossRef] [PubMed]

70. Liu, G.-P.; Zhang, Y.; Yao, X.-Q.; Zhang, C.-E.; Fang, J.; Wang, Q.; Wang, J.-Z. Activation of glycogen synthase kinase-3 inhibits protein phosphatase-2A and the underlying mechanisms. Neurobiol. Aging 2008, 29, 1348-1358. [CrossRef] [PubMed]

71. Marin, M.A.; Ziburkus, J.; Jankowsky, J.; Rasband, M.N. Amyloid- $\beta$ plaques disrupt axon initial segments. Exp. Neurol. 2016, 281, 93-98. [CrossRef] [PubMed]

72. Jazvinšćak Jembrek, M.; Hof, P.R.; Šimić, G. Ceramides in Alzheimer's Disease: Key Mediators of Neuronal Apoptosis Induced by Oxidative Stress and A $\beta$ Accumulation. Oxid. Med. Cell. Longev. 2015, 2015, 1-17. [CrossRef] [PubMed]

73. Jin, M.; Shepardson, N.; Yang, T.; Chen, G.; Walsh, D.; Selkoe, D.J. Soluble amyloid-protein dimers isolated from Alzheimer cortex directly induce Tau hyperphosphorylation and neuritic degeneration. Proc. Natl. Acad. Sci. USA 2011, 108, 5819-5824. [CrossRef] [PubMed]

74. Bloom, G.S. Amyloid- $\beta$ and Tau. JAMA Neurol. 2014, 71, 505. [CrossRef] [PubMed]

75. Stancu, I.-C.; Vasconcelos, B.; Terwel, D.; Dewachter, I. Models of $\beta$-amyloid induced Tau-pathology: The long and "folded" road to understand the mechanism. Mol. Neurodegener. 2014, 9, 51. [CrossRef] [PubMed]

76. Nery, L.R.; Eltz, N.S.; Hackman, C.; Fonseca, R.; Altenhofen, S.; Guerra, H.N.; Freitas, V.M.; Bonan, C.D.; Vianna, M.R.M.R. Brain Intraventricular Injection of Amyloid- $\beta$ in Zebrafish Embryo Impairs Cognition and Increases Tau Phosphorylation, Effects Reversed by Lithium. PLoS ONE 2014, 9, e105862. [CrossRef] [PubMed]

77. Huang, H.-C.; Jiang, Z.-F. Accumulated Amyloid- $\beta$ Peptide and Hyperphosphorylated Tau Protein: Relationship and Links in Alzheimer's Disease. J. Alzheimer's Dis. 2009, 16, 15-27. [CrossRef] [PubMed]

78. Magrane, J.; Rosen, K.M.; Smith, R.C.; Walsh, K.; Gouras, G.K.; Querfurth, H.W. Intraneuronal -Amyloid Expression Downregulates the Akt Survival Pathway and Blunts the Stress Response. J. Neurosci. 2005, 25, 10960-10969. [CrossRef] [PubMed]

79. Miller, E.C.; Teravskis, P.J.; Dummer, B.W.; Zhao, X.; Huganir, R.L.; Liao, D. Tau phosphorylation and tau mislocalization mediate soluble $\mathrm{A} \beta$ oligomer-induced AMPA glutamate receptor signaling deficits. Eur. J. Neurosci. 2014, 39, 1214-1224. [CrossRef] [PubMed]

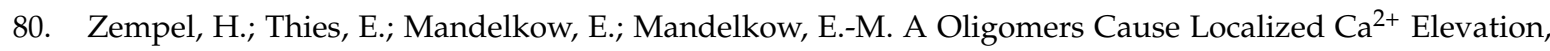
Missorting of Endogenous Tau into Dendrites, Tau Phosphorylation, and Destruction of Microtubules and Spines. J. Neurosci. 2010, 30, 11938-11950. [CrossRef] [PubMed]

81. Harris, C.D.; Ermak, G.; Davies, K.J.A. RCAN1-1L is overexpressed in neurons of Alzheimer's disease patients. FEBS J. 2007. [CrossRef] [PubMed]

82. Wong, H.; Levenga, J.; Cain, P.; Rothermel, B.; Klann, E.; Hoeffer, C. RCAN1 overexpression promotes age-dependent mitochondrial dysregulation related to neurodegeneration in Alzheimer's disease. Acta Neuropathol. 2015, 130, 829-843. [CrossRef] [PubMed]

83. Lloret, A.; Badia, M.-C.; Giraldo, E.; Ermak, G.; Alonso, M.-D.; Pallardó, F.V.; Davies, K.J.A.; Viña, J. Amyloid- $\beta$ Toxicity and Tau Hyperphosphorylation are Linked Via RCAN1 in Alzheimer's Disease. J. Alzheimer's Dis. 2011, 27, 701-709. [CrossRef] [PubMed]

84. Porta, S.; Serra, S.A.; Huch, M.; Valverde, M.A.; Llorens, F.; Estivill, X.; Arbonés, M.L.; Martí, E. RCAN1 (DSCR1) increases neuronal susceptibility to oxidative stress: A potential pathogenic process in neurodegeneration. Hum. Mol. Genet. 2007, 16, 1039-1050. [CrossRef] [PubMed]

85. Resende, R.; Ferreiro, E.; Pereira, C.; Oliveira, C.R. ER stress is involved in A $\beta$-induced GSK-3 $\beta$ activation and tau phosphorylation. J. Neurosci. Res. 2008, 86, 2091-2099. [CrossRef] [PubMed]

86. Magdesian, M.H.; Carvalho, M.M.V.F.; Mendes, F.A.; Saraiva, L.M.; Juliano, M.A.; Juliano, L.; Garcia-Abreu, J.; Ferreira, S.T. Amyloid- $\beta$ Binds to the Extracellular Cysteine-rich Domain of Frizzled and Inhibits Wnt/ $\beta$-Catenin Signaling. J. Biol. Chem. 2008, 283, 9359-9368. [CrossRef] [PubMed]

87. Götz, J.; Gladbach, A.; Pennanen, L.; van Eersel, J.; Schild, A.; David, D.; Ittner, L.M. Animal models reveal role for tau phosphorylation in human disease. Biochim. Biophys. Acta - Mol. Basis Dis. 2010, 1802, 860-871. [CrossRef] [PubMed]

88. Gómez-Sintes, R.; Hernández, F.; Lucas, J.J.; Avila, J. GSK-3 Mouse Models to Study Neuronal Apoptosis and Neurodegeneration. Front. Mol. Neurosci. 2011, 4, 45. [CrossRef] [PubMed] 
89. Chabrier, M.A.; Blurton-Jones, M.; Agazaryan, A.A.; Nerhus, J.L.; Martinez-Coria, H.; LaFerla, F.M. Soluble A Promotes Wild-Type Tau Pathology In vivo. J. Neurosci. 2012, 32, 17345-17350. [CrossRef] [PubMed]

90. McKee, A.C.; Carreras, I.; Hossain, L.; Ryu, H.; Klein, W.L.; Oddo, S.; LaFerla, F.M.; Jenkins, B.G.; Kowall, N.W.; Dedeoglu, A. Ibuprofen reduces A $\beta$, hyperphosphorylated tau and memory deficits in Alzheimer mice. Brain Res. 2008, 1207, 225-236. [CrossRef] [PubMed]

91. Lanzillotta, A.; Sarnico, I.; Benarese, M.; Branca, C.; Baiguera, C.; Hutter-Paier, B.; Windisch, M.; Spano, P.; Imbimbo, B.P.; Pizzi, M. The $\gamma$-Secretase Modulator CHF5074 Reduces the Accumulation of Native Hyperphosphorylated Tau in a Transgenic Mouse Model of Alzheimer's Disease. J. Mol. Neurosci. 2011, 45, 22-31. [CrossRef] [PubMed]

92. Jo, J.; Whitcomb, D.J.; Olsen, K.M.; Kerrigan, T.L.; Lo, S.-C.; Bru-Mercier, G.; Dickinson, B.; Scullion, S.; Sheng, M.; Collingridge, G.; Cho, K. A $\beta 1-42$ inhibition of LTP is mediated by a signaling pathway involving caspase-3, Akt1 and GSK-3ß. Nat. Neurosci. 2011, 14, 545-547. [CrossRef] [PubMed]

93. Arriagada, P.V.; Growdon, J.H.; Hedley-Whyte, E.T.; Hyman, B.T. Neurofibrillary tangles but not senile plaques parallel duration and severity of Alzheimer's disease. Neurology 1992, 42, 631-639. [CrossRef] [PubMed]

94. Duyckaerts, C.; Bennecib, M.; Grignon, Y.; Uchihara, T.; He, Y.; Piette, F.; Hauw, J.J. Modeling the relation between neurofibrillary tangles and intellectual status. Neurobiol. Aging 1997, 18, 267-273. [CrossRef]

95. Cho, H.; Choi, J.Y.; Hwang, M.S.; Lee, J.H.; Kim, Y.J.; Lee, H.M.; Lyoo, C.H.; Ryu, Y.H.; Lee, M.S. Tau PET in Alzheimer disease and mild cognitive impairment. Neurology 2016, 87, 375-383. [CrossRef] [PubMed]

96. Pontecorvo, M.J.; Devous, M.D.; Navitsky, M.; Lu, M.; Salloway, S.; Schaerf, F.W.; Jennings, D.; Arora, A.K.; McGeehan, A.; Lim, N.C.; et al. Relationships between flortaucipir PET tau binding and amyloid burden, clinical diagnosis, age and cognition. Brain 2017, 140, 334. [CrossRef] [PubMed]

97. Gamblin, T.C.; Chen, F.; Zambrano, A.; Abraha, A.; Lagalwar, S.; Guillozet, A.L.; Lu, M.; Fu, Y.; Garcia-Sierra, F.; et al. Caspase cleavage of tau: Linking amyloid and neurofibrillary tangles in Alzheimer's disease. Proc. Natl. Acad. Sci. USA 2003, 100, 10032-10037. [CrossRef] [PubMed]

98. Venero, J.L.; Burguillos, M.A.; Joseph, B. Caspases Playing in the Field of Neuroinflammation: Old and New Players. Dev. Neurosci. 2013, 35, 88-101. [CrossRef] [PubMed]

99. Gervais, F.G.; Xu, D.; Robertson, G.S.; Vaillancourt, J.P.; Zhu, Y.; Huang, J.; LeBlanc, A.; Smith, D.; Rigby, M.; Shearman, M.S.; et al. Involvement of caspases in proteolytic cleavage of Alzheimer's amyloid-beta precursor protein and amyloidogenic A beta peptide formation. Cell 1999, 97, 395-406. [CrossRef]

100. Stadelmann, C.; Deckwerth, T.L.; Srinivasan, A.; Bancher, C.; Brück, W.; Jellinger, K.; Lassmann, H. Activation of caspase- 3 in single neurons and autophagic granules of granulovacuolar degeneration in Alzheimer's disease. Evidence for apoptotic cell death. Am. J. Pathol. 1999, 155, 1459-1466. [CrossRef]

101. Rohn, T.T.; Head, E.; Nesse, W.H.; Cotman, C.W.; Cribbs, D.H. Activation of Caspase-8 in the Alzheimer's Disease Brain. Neurobiol. Dis. 2001, 8, 1006-1016. [CrossRef] [PubMed]

102. Rohn, T.T.; Head, E.; Su, J.H.; Anderson, A.J.; Bahr, B.A.; Cotman, C.W.; Cribbs, D.H. Correlation between caspase activation and neurofibrillary tangle formation in Alzheimer's disease. Am. J. Pathol. 2001, 158, 189-198. [CrossRef]

103. Su, J.H.; Zhao, M.; Anderson, A.J.; Srinivasan, A.; Cotman, C.W. Activated caspase-3 expression in Alzheimer's and aged control brain: correlation with Alzheimer pathology. Brain Res. 2001, 898, 350-357. [CrossRef]

104. Rohn, T.T.; Rissman, R.A.; Davis, M.C.; Kim, Y.E.; Cotman, C.W.; Head, E. Caspase-9 activation and caspase cleavage of tau in the Alzheimer's disease brain. Neurobiol. Dis. 2002, 11, 341-354. [CrossRef] [PubMed]

105. Gastard, M.C.; Troncoso, J.C.; Koliatsos, V.E. Caspase activation in the limbic cortex of subjects with early Alzheimer's disease. Ann. Neurol. 2003, 54, 393-398. [CrossRef] [PubMed]

106. Ren, Q.-G.; Liao, X.-M.; Chen, X.-Q.; Liu, G.-P.; Wang, J.-Z. Effects of tau phosphorylation on proteasome activity. FEBS Lett. 2007, 581, 1521-1528. [CrossRef] [PubMed]

107. Keck, S.; Nitsch, R.; Grune, T.; Ullrich, O. Proteasome inhibition by paired helical filament-tau in brains of patients with Alzheimer's disease. J. Neurochem. 2003, 85, 115-122. [CrossRef] [PubMed]

108. Ying, Z.; Wang, H.; Wang, G. The ubiquitin proteasome system as a potential target for the treatment of neurodegenerative diseases. Curr. Pharm. Des. 2013, 19, 3305-3314. [CrossRef] [PubMed] 
109. Olsson, B.; Lautner, R.; Andreasson, U.; Öhrfelt, A.; Portelius, E.; Bjerke, M.; Hölttä, M.; Rosén, C.; Olsson, C.; Strobel, G.; et al. CSF and blood biomarkers for the diagnosis of Alzheimer's disease: A systematic review and meta-analysis. Lancet Neurol. 2016, 15, 673-684. [CrossRef]

110. Hall, G.F.; Saman, S. Death or secretion? The demise of a plausible assumption about CSF-tau in Alzheimer Disease? Commun. Integr. Biol. 2012, 5, 623-626. [CrossRef] [PubMed]

111. Medina, M.; Avila, J. The role of extracellular Tau in the spreading of neurofibrillary pathology. Front. Cell. Neurosci. 2014, 8, 113. [CrossRef] [PubMed]

112. Seppälä, T.T.; Koivisto, A.M.; Hartikainen, P.; Helisalmi, S.; Soininen, H.; Herukka, S.-K. Longitudinal Changes of CSF Biomarkers in Alzheimer's Disease. J. Alzheimer's Dis. 2011, 25, 583-594. [CrossRef] [PubMed]

113. Pooler, A.M.; Phillips, E.C.; Lau, D.H.W.; Noble, W.; Hanger, D.P. Physiological release of endogenous tau is stimulated by neuronal activity. EMBO Rep. 2013, 14, 389-394. [CrossRef] [PubMed]

114. Yamada, K.; Cirrito, J.R.; Stewart, F.R.; Jiang, H.; Finn, M.B.; Holmes, B.B.; Binder, L.I.; Mandelkow, E.-M.; Diamond, M.I.; Lee, V.M.-Y.; Holtzman, D.M. In vivo Microdialysis Reveals Age-Dependent Decrease of Brain Interstitial Fluid Tau Levels in P301S Human Tau Transgenic Mice. J. Neurosci. 2011, 31, 13110-13117. [CrossRef] [PubMed]

115. Plouffe, V.; Mohamed, N.-V.; Rivest-McGraw, J.; Bertrand, J.; Lauzon, M.; Leclerc, N. Hyperphosphorylation and Cleavage at D421 Enhance Tau Secretion. PLoS ONE 2012, 7, e36873. [CrossRef] [PubMed]

116. Saman, S.; Kim, W.; Raya, M.; Visnick, Y.; Miro, S.; Saman, S.; Jackson, B.; McKee, A.C.; Alvarez, V.E.; Lee, N.C.Y.; Hall, G.F. Exosome-associated Tau Is Secreted in Tauopathy Models and Is Selectively Phosphorylated in Cerebrospinal Fluid in Early Alzheimer Disease. J. Biol. Chem. 2012, 287, 3842-3849. [CrossRef] [PubMed]

117. Wang, Y.; Balaji, V.; Kaniyappan, S.; Krüger, L.; Irsen, S.; Tepper, K.; Chandupatla, R.; Maetzler, W.; Schneider, A.; Mandelkow, E.; Mandelkow, E.-M. The release and trans-synaptic transmission of Tau via exosomes. Mol. Neurodegener. 2017, 12, 5. [CrossRef] [PubMed]

118. Selenica, M.-L.B.; Davtyan, H.; Housley, S.B.; Blair, L.J.; Gillies, A.; Nordhues, B.A.; Zhang, B.; Liu, J.; Gestwicki, J.E.; Lee, D.C.; Gordon, M.N.; Morgan, D.; Dickey, C.A. Epitope analysis following active immunization with tau proteins reveals immunogens implicated in tau pathogenesis. J. Neuroinflammation 2014, 11, 152. [CrossRef] [PubMed]

119. Doran, E.; Keator, D.; Head, E.; Phelan, M.J.; Kim, R.; Totoiu, M.; Barrio, J.R.; Small, G.W.; Potkin, S.G.; Lott, I.T. Down Syndrome, Partial Trisomy 21, and Absence of Alzheimer's Disease: The Role of APP. J. Alzheimer's Dis. 2017, 56, 459-470. [CrossRef] [PubMed]

120. Hu, N.-W.; Corbett, G.T.; Moore, S.; Klyubin, I.; O’Malley, T.T.; Walsh, D.M.; Livesey, F.J.; Rowan, M.J. Extracellular Forms of A $\beta$ and Tau from iPSC Models of Alzheimer's Disease Disrupt Synaptic Plasticity. Cell Rep. 2018, 23, 1932-1938. [CrossRef] [PubMed]

121. Dubal, D.B. The Way of Tau: Secretion and Synaptic Dysfunction. Trends Mol. Med. 2018, 24, 595-597. [CrossRef] [PubMed]

122. McEwan, W.A.; Falcon, B.; Vaysburd, M.; Clift, D.; Oblak, A.L.; Ghetti, B.; Goedert, M.; James, L.C. Cytosolic Fc receptor TRIM21 inhibits seeded tau aggregation. Proc. Natl. Acad. Sci. USA 2017, 114, 574-579. [CrossRef] [PubMed]

123. Pascual, G.; Wadia, J.S.; Zhu, X.; Keogh, E.; Kükrer, B.; van Ameijde, J.; Inganäs, H.; Siregar, B.; Perdok, G.; Diefenbach, O.; et al. Immunological memory to hyperphosphorylated tau in asymptomatic individuals. Acta Neuropathol. 2017, 133, 767-783. [CrossRef] [PubMed]

124. Agadjanyan, M.G.; Petrovsky, N.; Ghochikyan, A. A fresh perspective from immunologists and vaccine researchers: Active vaccination strategies to prevent and reverse Alzheimer's disease. Alzheimer's Dement. 2015, 11, 1246-1259. [CrossRef] [PubMed]

125. Delacourte, A.; David, J.P.; Sergeant, N.; Buée, L.; Wattez, A.; Vermersch, P.; Ghozali, F.; Fallet-Bianco, C.; Pasquier, F.; Lebert, F.; et al. The biochemical pathway of neurofibrillary degeneration in aging and Alzheimer's disease. Neurology 1999, 52, 1158-1165. [CrossRef] [PubMed]

126. Grober, E.; Dickson, D.; Sliwinski, M.J.; Buschke, H.; Katz, M.; Crystal, H.; Lipton, R.B. Memory and mental status correlates of modified Braak staging. Neurobiol. Aging 1999, 20, 573-579. [CrossRef] 
127. Zhou, L.; McInnes, J.; Wierda, K.; Holt, M.; Herrmann, A.G.; Jackson, R.J.; Wang, Y.-C.; Swerts, J.; Beyens, J.; Miskiewicz, K.; et al. Tau association with synaptic vesicles causes presynaptic dysfunction. Nat. Commun. 2017, 8, 15295. [CrossRef] [PubMed]

128. Furman, J.L.; Vaquer-Alicea, J.; White, C.L.; Cairns, N.J.; Nelson, P.T.; Diamond, M.I. Widespread tau seeding activity at early Braak stages. Acta Neuropathol. 2017, 133, 91-100. [CrossRef] [PubMed]

129. Holmes, B.B.; Furman, J.L.; Mahan, T.E.; Yamasaki, T.R.; Mirbaha, H.; Eades, W.C.; Belaygorod, L.; Cairns, N.J.; Holtzman, D.M.; Diamond, M.I. Proteopathic tau seeding predicts tauopathy in vivo. Proc. Natl. Acad. Sci. USA 2014, 111, E4376-E4385. [CrossRef] [PubMed]

130. Ahmed, Z.; Cooper, J.; Murray, T.K.; Garn, K.; McNaughton, E.; Clarke, H.; Parhizkar, S.; Ward, M.A.; Cavallini, A.; Jackson, S.; et al. A novel in vivo model of tau propagation with rapid and progressive neurofibrillary tangle pathology: The pattern of spread is determined by connectivity, not proximity. Acta Neuropathol. 2014, 127, 667-683. [CrossRef] [PubMed]

131. Clavaguera, F.; Bolmont, T.; Crowther, R.A.; Abramowski, D.; Frank, S.; Probst, A.; Fraser, G.; Stalder, A.K.; Beibel, M.; Staufenbiel, M.; et al. Transmission and spreading of tauopathy in transgenic mouse brain. Nat. Cell Biol. 2009, 11, 909-913. [CrossRef] [PubMed]

132. Dujardin, S.; Lécolle, K.; Caillierez, R.; Bégard, S.; Zommer, N.; Lachaud, C.; Carrier, S.; Dufour, N.; Aurégan, G.; Winderickx, J.; et al. Neuron-to-neuron wild-type Tau protein transfer through a trans-synaptic mechanism: Relevance to sporadic tauopathies. Acta Neuropathol. Commun. 2014, 2, 14. [CrossRef] [PubMed]

133. Asai, H.; Ikezu, S.; Tsunoda, S.; Medalla, M.; Luebke, J.; Haydar, T.; Wolozin, B.; Butovsky, O.; Kügler, S.; Ikezu, T. Depletion of microglia and inhibition of exosome synthesis halt tau propagation. Nat. Neurosci. 2015, 18, 1584-1593. [CrossRef] [PubMed]

134. Stobart, J.L.; Anderson, C.M. Multifunctional role of astrocytes as gatekeepers of neuronal energy supply. Front. Cell. Neurosci. 2013, 7, 38. [CrossRef] [PubMed]

135. Liddelow, S.A.; Guttenplan, K.A.; Clarke, L.E.; Bennett, F.C.; Bohlen, C.J.; Schirmer, L.; Bennett, M.L.; Münch, A.E.; Chung, W.-S.; Peterson, T.C.; et al. Neurotoxic reactive astrocytes are induced by activated microglia. Nature 2017, 541, 481-487. [CrossRef] [PubMed]

136. Liddelow, S.; Barres, B. SnapShot: Astrocytes in Health and Disease. Cell 2015, 162, 1170. [CrossRef] [PubMed]

137. Liddelow, S.A.; Barres, B.A. Reactive Astrocytes: Production, Function, and Therapeutic Potential. Immunity 2017, 46, 957-967. [CrossRef] [PubMed]

138. Laurent, C.; Dorothée, G.; Hunot, S.; Martin, E.; Monnet, Y.; Duchamp, M.; Dong, Y.; Légeron, F.-P.; Leboucher, A.; Burnouf, S.; et al. Hippocampal T cell infiltration promotes neuroinflammation and cognitive decline in a mouse model of tauopathy. Brain 2017, 140, 184-200. [CrossRef] [PubMed]

139. Rodríguez-Arellano, J.J.; Parpura, V.; Zorec, R.; Verkhratsky, A. Astrocytes in physiological aging and Alzheimer's disease. Neuroscience 2016, 323, 170-182. [CrossRef] [PubMed]

140. Forman, M.S.; Lal, D.; Zhang, B.; Dabir, D.V.; Swanson, E.; Lee, V.M.-Y.; Trojanowski, J.Q. Transgenic Mouse Model of Tau Pathology in Astrocytes Leading to Nervous System Degeneration. J. Neurosci. 2005, 25, 3539-3550. [CrossRef] [PubMed]

141. Nimmerjahn, A.; Kirchhoff, F.; Helmchen, F. Resting Microglial Cells Are Highly Dynamic Surveillants of Brain Parenchyma in vivo. Science (80-. ). 2005, 308, 1314-1318. [CrossRef] [PubMed]

142. Paolicelli, R.C.; Bisht, K.; Tremblay, M.-È. Fractalkine regulation of microglial physiology and consequences on the brain and behavior. Front. Cell. Neurosci. 2014, 8, 129. [CrossRef] [PubMed]

143. Walker, D.G.; Lue, L.-F. Understanding the neurobiology of CD200 and the CD200 receptor: A therapeutic target for controlling inflammation in human brains? Future Neurol. 2013, 8, 321-332. [CrossRef] [PubMed]

144. Wohleb, E.S. Neuron-Microglia Interactions in Mental Health Disorders: "For Better, and For Worse". Front. Immunol. 2016, 7, 544. [CrossRef] [PubMed]

145. Guillot-Sestier, M.-V.; Doty, K.R.; Town, T. Innate Immunity Fights Alzheimer's Disease. Trends Neurosci. 2015, 38, 674-681. [CrossRef] [PubMed]

146. Heneka, M.T.; Golenbock, D.T.; Latz, E. Innate immunity in Alzheimer's disease. Nat. Immunol. 2015, 16, 229-236. [CrossRef] [PubMed]

147. Fan, Z.; Brooks, D.J.; Okello, A.; Edison, P. An early and late peak in microglial activation in Alzheimer's disease trajectory. Brain 2017, 140, 349. [CrossRef] [PubMed] 
148. Fan, Z.; Okello, A.A.; Brooks, D.J.; Edison, P. Longitudinal influence of microglial activation and amyloid on neuronal function in Alzheimer's disease. Brain 2015, 138, 3685-3698. [CrossRef] [PubMed]

149. Keren-Shaul, H.; Spinrad, A.; Weiner, A.; Matcovitch-Natan, O.; Dvir-Szternfeld, R.; Ulland, T.K.; David, E.; Baruch, K.; Lara-Astaiso, D.; Toth, B.; et al. A Unique Microglia Type Associated with Restricting Development of Alzheimer's Disease. Cell 2017, 169, 1276-1290. [CrossRef] [PubMed]

150. Heneka, M.T.; Nadrigny, F.; Regen, T.; Martinez-Hernandez, A.; Dumitrescu-Ozimek, L.; Terwel, D.; Jardanhazi-Kurutz, D.; Walter, J.; Kirchhoff, F.; Hanisch, U.-K.; et al. Locus ceruleus controls Alzheimer's disease pathology by modulating microglial functions through norepinephrine. Proc. Natl. Acad. Sci. USA 2010, 107, 6058-6063. [CrossRef] [PubMed]

151. Kelly, S.C.; He, B.; Perez, S.E.; Ginsberg, S.D.; Mufson, E.J.; Counts, S.E. Locus coeruleus cellular and molecular pathology during the progression of Alzheimer's disease. Acta Neuropathol. Commun. 2017, 5, 8. [CrossRef] [PubMed]

152. Gabbita, S.P.; Johnson, M.F.; Kobritz, N.; Eslami, P.; Poteshkina, A.; Varadarajan, S.; Turman, J.; Zemlan, F.; Harris-White, M.E. Oral TNF $\alpha$ Modulation Alters Neutrophil Infiltration, Improves Cognition and Diminishes Tau and Amyloid Pathology in the 3xTgAD Mouse Model. PLoS ONE 2015, 10, e0137305. [CrossRef] [PubMed]

153. Zenaro, E.; Pietronigro, E.; Bianca, V.D.; Piacentino, G.; Marongiu, L.; Budui, S.; Turano, E.; Rossi, B.; Angiari, S.; Dusi, S.; et al. Neutrophils promote Alzheimer's disease-ike pathology and cognitive decline via LFA-1 integrin. Nat. Med. 2015, 21, 880-886. [CrossRef] [PubMed]

154. El Khoury, J.; Toft, M.; Hickman, S.E.; Means, T.K.; Terada, K.; Geula, C.; Luster, A.D. Ccr2 deficiency impairs microglial accumulation and accelerates progression of Alzheimer-like disease. Nat. Med. 2007, 13, 432-438. [CrossRef] [PubMed]

155. Naert, G.; Rivest, S. CC Chemokine Receptor 2 Deficiency Aggravates Cognitive Impairments and Amyloid Pathology in a Transgenic Mouse Model of Alzheimer's Disease. J. Neurosci. 2011, 31, 6208-6220. [CrossRef] [PubMed]

156. Gyoneva, S.; Kim, D.; Katsumoto, A.; Kokiko-Cochran, O.N.; Lamb, B.T.; Ransohoff, R.M. Ccr2 deletion dissociates cavity size and tau pathology after mild traumatic brain injury. J. Neuroinflammation 2015, 12, 228. [CrossRef] [PubMed]

157. Schraen-Maschke, S.; Sergeant, N.; Dhaenens, C.-M.; Bombois, S.; Deramecourt, V.; Caillet-Boudin, M.-L.; Pasquier, F.; Maurage, C.-A.; Sablonnière, B.; Vanmechelen, E.; et al. Tau as a biomarker of neurodegenerative diseases. Biomark. Med. 2008, 2, 363-384. [CrossRef] [PubMed]

158. Simonsen, A.H.; Herukka, S.-K.; Andreasen, N.; Baldeiras, I.; Bjerke, M.; Blennow, K.; Engelborghs, S.; Frisoni, G.B.; Gabryelewicz, T.; Galluzzi, S.; et al. Recommendations for CSF AD biomarkers in the diagnostic evaluation of dementia. Alzheimer's Dement. 2017, 13, 274-284. [CrossRef] [PubMed]

159. Lee, V.M.-Y.; Goedert, M.; Trojanowski, J.Q. Neurodegenerative Tauopathies. Annu. Rev. Neurosci. 2001, 24, 1121-1159. [CrossRef] [PubMed]

160. Ballatore, C.; Lee, V.M.-Y.; Trojanowski, J.Q. Tau-mediated neurodegeneration in Alzheimer's disease and related disorders. Nat. Rev. Neurosci. 2007, 8, 663-672. [CrossRef] [PubMed]

161. Wolfe, M.S. The role of tau in neurodegenerative diseases and its potential as a therapeutic target. Scientifica (Cairo). 2012, 2012, 796024. [CrossRef] [PubMed]

162. Beckett, L.A.; Harvey, D.J.; Gamst, A.; Donohue, M.; Kornak, J.; Zhang, H.; Kuo, J.H.; Alzheimer's Disease Neuroimaging Initiative. The Alzheimer's Disease Neuroimaging Initiative: Annual change in biomarkers and clinical outcomes. Alzheimers. Dement. 2010, 6, 257-264. [CrossRef] [PubMed]

163. Ritchie, C.; Smailagic, N.; Noel-Storr, A.H.; Ukoumunne, O.; Ladds, E.C.; Martin, S. CSF tau and the CSF tau/ABeta ratio for the diagnosis of Alzheimer's disease dementia and other dementias in people with mild cognitive impairment (MCI). Cochrane Database Syst. Rev. 2017, 3, CD010803. [CrossRef] [PubMed]

164. Inekci, D.; Henriksen, K.; Linemann, T.; Karsdal, M.A.; Habib, A.; Bisgaard, C.; Eriksen, F.B.; Vilholm, O.J. Serum Fragments of Tau for the Differential Diagnosis of Alzheimer's Disease. Curr. Alzheimer Res. 2015, 12, 829-836. [CrossRef] [PubMed]

165. Nordberg, A.; Rinne, J.O.; Kadir, A.; Långström, B. The use of PET in Alzheimer disease. Nat. Rev. Neurol. 2010, 6, 78-87. [CrossRef] [PubMed]

166. Marcus, C.; Mena, E.; Subramaniam, R.M. Brain PET in the diagnosis of Alzheimer's disease. Clin. Nucl. Med. 2014, 39. [CrossRef] [PubMed] 
167. Goedert, M. Tau protein and neurodegeneration. Semin. Cell Dev. Biol. 2004, 15, 45-49. [CrossRef] [PubMed]

168. Cairns, N.J.; Bigio, E.H.; Mackenzie, I.R.A.; Neumann, M.; Lee, V.M.-Y.; Hatanpaa, K.J.; White, C.L.; Schneider, J.A.; Grinberg, L.T.; Halliday, G.; et al. Consortium for Frontotemporal Lobar Degeneration Neuropathologic diagnostic and nosologic criteria for frontotemporal lobar degeneration: consensus of the Consortium for Frontotemporal Lobar Degeneration. Acta Neuropathol. 2007, 114, 5-22. [CrossRef] [PubMed]

169. Buée, L.; Bussière, T.; Buée-Scherrer, V.; Delacourte, A.; Hof, P.R. Tau protein isoforms, phosphorylation and role in neurodegenerative disorders. Brain Res. Brain Res. Rev. 2000, 33, 95-130. [CrossRef]

170. Gambhir, S.S. Molecular imaging of cancer with positron emission tomography. Nat. Rev. Cancer 2002, 2, 683-693. [CrossRef] [PubMed]

171. Wang, L.; Benzinger, T.L.; Su, Y.; Christensen, J.; Friedrichsen, K.; Aldea, P.; McConathy, J.; Cairns, N.J.; Fagan, A.M.; Morris, J.C.; Ances, B.M. Evaluation of Tau Imaging in Staging Alzheimer Disease and Revealing Interactions Between $\beta$-Amyloid and Tauopathy. JAMA Neurol. 2016, 73, 1070-1077. [CrossRef] [PubMed]

172. Brosch, J.R.; Farlow, M.R.; Risacher, S.L.; Apostolova, L.G. Tau Imaging in Alzheimer's Disease Diagnosis and Clinical Trials. Neurotherapeutics 2017, 14, 62-68. [CrossRef] [PubMed]

173. Chien, D.T.; Bahri, S.; Szardenings, A.K.; Walsh, J.C.; Mu, F.; Su, M.-Y.; Shankle, W.R.; Elizarov, A.; Kolb, H.C. Early Clinical PET Imaging Results with the Novel PHF-Tau Radioligand [ $\left.\mathrm{F}^{18}\right]-\mathrm{T} 807$. J. Alzheimer's Dis. 2013, 34, 457-468. [CrossRef] [PubMed]

174. Xia, C.-F.; Arteaga, J.; Chen, G.; Gangadharmath, U.; Gomez, L.F.; Kasi, D.; Lam, C.; Liang, Q.; Liu, C.; Mocharla, V.P.; et al. $\left[{ }^{18} \mathrm{~F}\right] \mathrm{T} 807$, a novel tau positron emission tomography imaging agent for Alzheimer's disease. Alzheimer's Dement. 2013, 9, 666-676. [CrossRef] [PubMed]

175. Maruyama, M.; Shimada, H.; Suhara, T.; Shinotoh, H.; Ji, B.; Maeda, J.; Zhang, M.-R.; Trojanowski, J.Q.; Lee, V.M.-Y.; Ono, M.; et al. Imaging of Tau Pathology in a Tauopathy Mouse Model and in Alzheimer Patients Compared to Normal Controls. Neuron 2013, 79, 1094-1108. [CrossRef] [PubMed]

176. Okamura, N.; Furumoto, S.; Fodero-Tavoletti, M.T.; Mulligan, R.S.; Harada, R.; Yates, P.; Pejoska, S.; Kudo, Y.; Masters, C.L.; Yanai, K.; et al. Non-invasive assessment of Alzheimer's disease neurofibrillary pathology using 18F-THK5105 PET. Brain 2014, 137, 1762-1771. [CrossRef] [PubMed]

177. Marquié, M.; Normandin, M.D.; Vanderburg, C.R.; Costantino, I.M.; Bien, E.A.; Rycyna, L.G.; Klunk, W.E.; Mathis, C.A.; Ikonomovic, M.D.; Debnath, M.L.; et al. Validating novel tau positron emission tomography tracer [F-18]-AV-1451 (T807) on postmortem brain tissue. Ann. Neurol. 2015, 78, 787-800. [CrossRef] [PubMed]

178. Villemagne, V.L.; Fodero-Tavoletti, M.T.; Masters, C.L.; Rowe, C.C. Tau imaging: Early progress and future directions. Lancet Neurol. 2015, 14, 114-124. [CrossRef]

179. Ossenkoppele, R.; Schonhaut, D.R.; Baker, S.L.; O’Neil, J.P.; Janabi, M.; Ghosh, P.M.; Santos, M.; Miller, Z.A.; Bettcher, B.M.; Gorno-Tempini, M.L.; et al. Tau, amyloid, and hypometabolism in a patient with posterior cortical atrophy. Ann. Neurol. 2015, 77, 338-342. [CrossRef] [PubMed]

180. Villemagne, V.L.; Okamura, N. In vivo tau imaging: Obstacles and progress. Alzheimer's Dement. 2014, 10, S254-S264. [CrossRef] [PubMed]

181. Villemagne, V.L.; Furumoto, S.; Fodero-Tavoletti, M.; Harada, R.; Mulligan, R.S.; Kudo, Y.; Masters, C.L.; Yanai, K.; Rowe, C.C.; Okamura, N. The challenges of tau imaging. Future Neurol. 2012, 7, 409-421. [CrossRef]

182. Chien, D.T.; Szardenings, A.K.; Bahri, S.; Walsh, J.C.; Mu, F.; Xia, C.; Shankle, W.R.; Lerner, A.J.; Su, M.-Y.; Elizarov, A.; et al. Early Clinical PET Imaging Results with the Novel PHF-Tau Radioligand [F18]-T808. J. Alzheimer's Dis. 2013, 38, 171-184. [CrossRef] [PubMed]

183. James, O.G.; Doraiswamy, P.M.; Borges-Neto, S. PET Imaging of Tau Pathology in Alzheimer's Disease and Tauopathies. Front. Neurol. 2015, 6, 38. [CrossRef] [PubMed]

184. Johnson, K.A.; Schultz, A.; Betensky, R.A.; Becker, J.A.; Sepulcre, J.; Rentz, D.; Mormino, E.; Chhatwal, J.; Amariglio, R.; Papp, K.; et al. Tau positron emission tomographic imaging in aging and early Alzheimer disease. Ann. Neurol. 2016, 79, 110-119. [CrossRef] [PubMed]

185. Schöll, M.; Lockhart, S.N.; Schonhaut, D.R.; O’Neil, J.P.; Janabi, M.; Ossenkoppele, R.; Baker, S.L.; Vogel, J.W.; Faria, J.; Schwimmer, H.D.; Rabinovici, G.D.; Jagust, W.J. PET Imaging of Tau Deposition in the Aging Human Brain. Neuron 2016, 89, 971-982. [CrossRef] [PubMed]

186. Schwarz, A.J.; Yu, P.; Miller, B.B.; Shcherbinin, S.; Dickson, J.; Navitsky, M.; Joshi, A.D.; Devous, M.D.; Mintun, M.S. Regional profiles of the candidate tau PET ligand ${ }^{18}$ F-AV-1451 recapitulate key features of Braak histopathological stages. Brain 2016, 139, 1539-1550. [CrossRef] [PubMed] 
187. Dickerson, B.C.; Bakkour, A.; Salat, D.H.; Feczko, E.; Pacheco, J.; Greve, D.N.; Grodstein, F.; Wright, C.I.; Blacker, D.; Rosas, H.D.; et al. The Cortical Signature of Alzheimer's Disease: Regionally Specific Cortical Thinning Relates to Symptom Severity in Very Mild to Mild AD Dementia and is Detectable in Asymptomatic Amyloid-Positive Individuals. Cereb. Cortex 2009, 19, 497-510. [CrossRef] [PubMed]

188. Vemuri, P.; Whitwell, J.L.; Kantarci, K.; Josephs, K.A.; Parisi, J.E.; Shiung, M.S.; Knopman, D.S.; Boeve, B.F.; Petersen, R.C.; Dickson, D.W.; et al. Antemortem MRI based STructural Abnormality iNDex (STAND)-scores correlate with postmortem Braak neurofibrillary tangle stage. Neuroimage 2008, 42, 559-567. [CrossRef] [PubMed]

189. Wang, L.; Benzinger, T.L.; Hassenstab, J.; Blazey, T.; Owen, C.; Liu, J.; Fagan, A.M.; Morris, J.C.; Ances, B.M. Spatially distinct atrophy is linked to -amyloid and tau in preclinical Alzheimer disease. Neurology 2015, 84, 1254-1260. [CrossRef] [PubMed]

190. Jack, C.R.; Knopman, D.S.; Jagust, W.J.; Petersen, R.C.; Weiner, M.W.; Aisen, P.S.; Shaw, L.M.; Vemuri, P.; Wiste, H.J.; Weigand, S.D.; et al. Tracking pathophysiological processes in Alzheimer's disease: An updated hypothetical model of dynamic biomarkers. Lancet Neurol. 2013, 12, 207-216. [CrossRef]

191. Shimada, H.; Kitamura, S.; Shinotoh, H.; Endo, H.; Niwa, F.; Hirano, S.; Kimura, Y.; Zhang, M.-R.; Kuwabara, S.; Suhara, T.; et al. Association between A $\beta$ and tau accumulations and their influence on clinical features in aging and Alzheimer's disease spectrum brains: A [11C]PBB3-PET study. Alzheimer's Dement. (Amsterdam, Netherlands) 2017, 6, 11-20. [CrossRef] [PubMed]

192. Fodero-Tavoletti, M.T.; Okamura, N.; Furumoto, S.; Mulligan, R.S.; Connor, A.R.; McLean, C.A.; Cao, D.; Rigopoulos, A.; Cartwright, G.A.; O'Keefe, G.; et al. 18F-THK523: A novel in vivo tau imaging ligand for Alzheimer's disease. Brain 2011, 134, 1089-1100. [CrossRef] [PubMed]

193. Harada, R.; Okamura, N.; Furumoto, S.; Tago, T.; Maruyama, M.; Higuchi, M.; Yoshikawa, T.; Arai, H.; Iwata, R.; Kudo, Y.; et al. Comparison of the binding characteristics of [18F]THK-523 and other amyloid imaging tracers to Alzheimer's disease pathology. Eur. J. Nucl. Med. Mol. Imaging 2013, 40, 125-132. [CrossRef] [PubMed]

194. Bellucci, A.; Bugiani, O.; Ghetti, B.; Spillantini, M.G. Presence of reactive microglia and neuroinflammatory mediators in a case of frontotemporal dementia with P301S mutation. Neurodegener. Dis. 2011, 8, 221-229. [CrossRef] [PubMed]

195. Schofield, E.; Kersaitis, C.; Shepherd, C.E.; Kril, J.J.; Halliday, G.M. Severity of gliosis in Pick's disease and frontotemporal lobar degeneration: Tau-positive glia differentiate these disorders. Brain 2003, 126, 827-840. [CrossRef] [PubMed]

196. Bellucci, A.; Westwood, A.J.; Ingram, E.; Casamenti, F.; Goedert, M.; Spillantini, M.G. Induction of Inflammatory Mediators and Microglial Activation in Mice Transgenic for Mutant Human P301S Tau Protein. Am. J. Pathol. 2004, 165, 1643-1652. [CrossRef]

197. Maphis, N.; Xu, G.; Kokiko-Cochran, O.N.; Jiang, S.; Cardona, A.; Ransohoff, R.M.; Lamb, B.T.; Bhaskar, K. Reactive microglia drive tau pathology and contribute to the spreading of pathological tau in the brain. Brain 2015, 138, 1738-1755. [CrossRef] [PubMed]

198. Yoshiyama, Y.; Higuchi, M.; Zhang, B.; Huang, S.-M.; Iwata, N.; Saido, T.C.; Maeda, J.; Suhara, T.; Trojanowski, J.Q.; Lee, V.M.-Y. Synapse Loss and Microglial Activation Precede Tangles in a P301S Tauopathy Mouse Model. Neuron 2007, 53, 337-351. [CrossRef] [PubMed]

199. Heneka, M.T.; Kummer, M.P.; Stutz, A.; Delekate, A.; Schwartz, S.; Vieira-Saecker, A.; Griep, A.; Axt, D.; Remus, A.; Tzeng, T.-C.; et al. NLRP3 is activated in Alzheimer's disease and contributes to pathology in APP/PS1 mice. Nature 2012, 493, 674-678. [CrossRef] [PubMed]

200. Garwood, C.J.; Cooper, J.D.; Hanger, D.P.; Noble, W. Anti-inflammatory impact of minocycline in a mouse model of tauopathy. Front. psychiatry 2010, 1, 136. [CrossRef] [PubMed]

201. Noble, W.; Garwood, C.; Stephenson, J.; Kinsey, A.M.; Hanger, D.P.; Anderton, B.H. Minocycline reduces the development of abnormal tau species in models of Alzheimer's disease. FASEB J. 2009, 23, 739-750. [CrossRef] [PubMed]

202. Borsini, A.; Zunszain, P.A.; Thuret, S.; Pariante, C.M. The role of inflammatory cytokines as key modulators of neurogenesis. Trends Neurosci. 2015, 38, 145-157. [CrossRef] [PubMed]

203. Lewerenz, J.; Maher, P. Chronic Glutamate Toxicity in Neurodegenerative Diseases-What is the Evidence? Front. Neurosci. 2015, 9, 469. [CrossRef] [PubMed] 
204. Hu, N.-W.; Ondrejcak, T.; Rowan, M.J. Glutamate receptors in preclinical research on Alzheimer's disease: Update on recent advances. Pharmacol. Biochem. Behav. 2012, 100, 855-862. [CrossRef] [PubMed]

205. Hardy, J.; Selkoe, D.J. The Amyloid Hypothesis of Alzheimer's Disease: Progress and Problems on the Road to Therapeutics. Science 2002, 297, 353-356. [CrossRef] [PubMed]

206. Golde, T.E. Alzheimer disease therapy: Can the amyloid cascade be halted? J. Clin. Invest. 2003, 111, 11-18. [CrossRef] [PubMed]

207. Holtzman, D.M.; Bales, K.R.; Paul, S.M.; DeMattos, R.B. Abeta immunization and anti-Abeta antibodies: Potential therapies for the prevention and treatment of Alzheimer's disease. Adv. Drug Deliv. Rev. 2002, 54, 1603-1613. [CrossRef]

208. Mikulca, J.A.; Nguyen, V.; Gajdosik, D.A.; Teklu, S.G.; Giunta, E.A.; Lessa, E.A.; Tran, C.H.; Terak, E.C.; Raffa, R.B. Potential novel targets for Alzheimer pharmacotherapy: II. Update on secretase inhibitors and related approaches. J. Clin. Pharm. Ther. 2014, 39, 25-37. [CrossRef] [PubMed]

209. Panza, F.; Frisardi, V.; Solfrizzi, V.; Imbimbo, B.P.; Logroscino, G.; Santamato, A.; Greco, A.; Seripa, D.; Pilotto, A. Interacting with $\gamma$-secretase for treating Alzheimer's disease: From inhibition to modulation. Curr. Med. Chem. 2011, 18, 5430-5447. [CrossRef] [PubMed]

210. Ittner, A.; Chua, S.W.; Bertz, J.; Volkerling, A.; van der Hoven, J.; Gladbach, A.; Przybyla, M.; Bi, M.; van Hummel, A.; Stevens, C.H.; et al. Site-specific phosphorylation of tau inhibits amyloid- $\beta$ toxicity in Alzheimer's mice. Science 2016, 354, 904-908. [CrossRef] [PubMed]

211. Gozes, I. Tau as a Drug Target in Alzheimer's Disease. J. Mol. Neurosci. 2002, 19, 337-338. [CrossRef]

212. Loy, R.; Tariot, P.N. Neuroprotective properties of valproate: Potential benefit for AD and tauopathies. J. Mol. Neurosci. 2002, 19, 303-307. [CrossRef]

213. Freland, L.; Beaulieu, J.-M. Inhibition of GSK3 by lithium, from single molecules to signaling networks. Front. Mol. Neurosci. 2012, 5, 14. [CrossRef] [PubMed]

214. Chen, L.-M.; Xiong, Y.-S.; Kong, F.-L.; Qu, M.; Wang, Q.; Chen, X.-Q.; Wang, J.-Z.; Zhu, L.-Q. Neuroglobin attenuates Alzheimer-like tau hyperphosphorylation by activating Akt signaling. J. Neurochem. 2012, 120, 157-164. [CrossRef] [PubMed]

215. Tell, V.; Hilgeroth, A. Recent developments of protein kinase inhibitors as potential AD therapeutics. Front. Cell. Neurosci. 2013, 7, 189. [CrossRef] [PubMed]

216. Pedersen, J.T.; Sigurdsson, E.M. Tau immunotherapy for Alzheimer's disease. Trends Mol. Med. 2015, 21, 394-402. [CrossRef] [PubMed]

217. Kontsekova, E.; Zilka, N.; Kovacech, B.; Novak, P.; Novak, M. First-in-man tau vaccine targeting structural determinants essential for pathological tau-Tau interaction reduces tau oligomerisation and neurofibrillary degeneration in an Alzheimer's disease model. Alzheimers. Res. Ther. 2014, 6, 44. [CrossRef] [PubMed]

218. Ballatore, C.; Brunden, K.R.; Huryn, D.M.; Trojanowski, J.Q.; Lee, V.M.-Y.; Smith, A.B. III Microtubule stabilizing agents as potential treatment for Alzheimer's disease and related neurodegenerative tauopathies. J. Med. Chem. 2012, 55, 8979-8996. [CrossRef] [PubMed]

219. Khan, R.; Nirzhor, S.; Akter, R. A Review of the Recent Advances Made with SIRT6 and its Implications on Aging Related Processes, Major Human Diseases, and Possible Therapeutic Targets. Biomolecules 2018, 8, 44. [CrossRef] [PubMed]

220. Jung, E.S.; Choi, H.; Song, H.; Hwang, Y.J.; Kim, A.; Ryu, H.; Mook-Jung, I. p53-dependent SIRT6 expression protects A $\beta 42$-induced DNA damage. Sci. Rep. 2016, 6, 25628. [CrossRef] [PubMed]

(C) 2018 by the authors. Licensee MDPI, Basel, Switzerland. This article is an open access article distributed under the terms and conditions of the Creative Commons Attribution (CC BY) license (http://creativecommons.org/licenses/by/4.0/). 